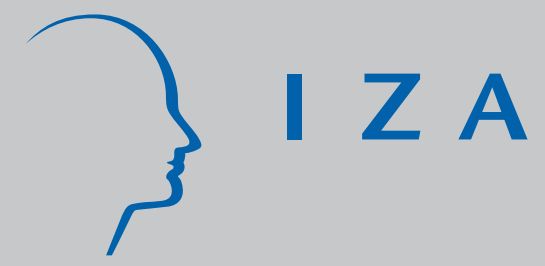

IZA DP No. 9578

Are Starting Wages Reduced by an Insurance Premium for Preventing Wage Decline?

Testing the Prediction of Harris and Holmstrom (1982)

Joop Hartog

Pedro Raposo

December 2015 


\title{
Are Starting Wages Reduced by an Insurance Premium for Preventing Wage Decline? Testing the Prediction of Harris and Holmstrom (1982)
}

\author{
Joop Hartog \\ University of Amsterdam \\ and IZA \\ Pedro Raposo \\ Catolica Lisbon School of Business and Economics
}

Discussion Paper No. 9578

December 2015

\author{
IZA \\ P.O. Box 7240 \\ 53072 Bonn \\ Germany \\ Phone: +49-228-3894-0 \\ Fax: +49-228-3894-180 \\ E-mail: iza@iza.org
}

Any opinions expressed here are those of the author(s) and not those of IZA. Research published in this series may include views on policy, but the institute itself takes no institutional policy positions. The IZA research network is committed to the IZA Guiding Principles of Research Integrity.

The Institute for the Study of Labor (IZA) in Bonn is a local and virtual international research center and a place of communication between science, politics and business. IZA is an independent nonprofit organization supported by Deutsche Post Foundation. The center is associated with the University of Bonn and offers a stimulating research environment through its international network, workshops and conferences, data service, project support, research visits and doctoral program. IZA engages in (i) original and internationally competitive research in all fields of labor economics, (ii) development of policy concepts, and (iii) dissemination of research results and concepts to the interested public.

IZA Discussion Papers often represent preliminary work and are circulated to encourage discussion. Citation of such a paper should account for its provisional character. A revised version may be available directly from the author. 
IZA Discussion Paper No. 9578

December 2015

\section{ABSTRACT}

\section{Are Starting Wages Reduced by an Insurance Premium for Preventing Wage Decline? Testing the Prediction of Harris and Holmstrom (1982)*}

In the model of Harris and Holmstrom (1982) workers pay an insurance premium to prevent a wage decline. As employers are unable to assess the ability of a labour market entrant, they would offer a wage equal to expected productivity of the worker's category and adjust it with unfolding information on true individual productivity. Workers are willing to accept a reduction in starting wage to prevent a reduction in their wage when their productivity is revealed to be below the expected value for their category. While Harris and Holmstrom indicate crystal clear how the prediction can be tested, their prescription has never been applied. Using Portuguese data covering virtually the entire labour force, we find that the prediction is unequivocally rejected. We interpret the results instead as confirmation of earlier results showing that workers are compensated for the financial risk of investing in an education.

JEL Classification: J310, D860

Keywords: $\quad$ risk premium, starting wages, unknown productivity, wage rigidity

Corresponding author:

Joop Hartog

Research Institute Amsterdam School of Economics (ASE-RI)

University of Amsterdam

P.O. Box 15867

1001 NJ Amsterdam

The Netherlands

E-mail: j.hartog@uva.nl

\footnotetext{
* We gratefully acknowledge comments by Ana Rute Cardoso, Dan Hamermesh, Chris Muris, Michael Waldman and Pedro Portugal and other participants at the Meetings of the Portuguese Economic Journal in the Azores, seminar participants at Linked Employer-employee data workshop in 2015 and at Waikato University and Motu Public Policy Seminar Wellington.
} 


\section{The Harris and Holmstrom prediction}

In an influential paper, Harris and Holstrom (1982) predicted that starting wages for labour market entrants are depressed by an insurance premium that employers withhold in return for the guarantee that wages will not be reduced when initally unknown worker productivity is revealed. A standard (myopic) competitive model with risk neutral agents would predict that in the face of unknown productivity of entering graduates, employers would pay the expected productivity of the graduates and then adjust wages as they gradually learn workers' individual productivity. However, this may entail wage decline for workers revealed to have low productivity. To avoid that, workers prefer an implicit contract where the employer rules out wage reductions and workers accept a starting wage below expected productivity. The insurance premium will depend on the dispersion of productivity in the worker's class. In their own words, Harris and Holmstrom (HH henceforth) "show that the market wage of a worker is his current mean perceived productivity minus a term which depends only on his age and the precision of beliefs about his productivity. This second term may be thought of as an insurance premium for the downward rigidity of wages. We show that this premium decreases both with age and precision." Risk neutral firms will offer a contract with downward wage rigidity and an insurance premium that gradually diminishes as information on ability becomes more precise.

Most interestingly, $\mathrm{HH}$ provide a precise recipe for testing their prediction ${ }^{1}$ : uncertainty about productivity of the youngest workers is indicated by the observed dispersion of productivity (or ability) $\eta$ of the oldest workers. In their own words:

"That is the distribution of estimated abilities in the population of the oldest workers is approximately the same as the initial prior distribution of abilities for the youngest workers. The distribution of estimated (or expected) abilities in the population starts as a point mass $m_{1}(e)$ for new workers with education e and gradually spreads out to coincide (approximately) with the prior distribution of $\eta$ " (o.c. 318).

$\mathrm{HH}$ prove (Theorem $2 \mathrm{ii,} \mathrm{p} 323$ ) that the insurance premium that is deducted from expected productivity is strictly decreasing in precision $h$, that is, strictly increasing in the variance $1 / h^{2}$.

In this paper, we set out to test the prediction that starting wages are lower if the perceived ability variance of new workers is larger. Rather surprisingly, the test

\footnotetext{
${ }^{1}$ The Harris and Holmstrom paper offers more predictions than the one on the insurance premium that we single out here. They match their predictions with stylized facts, not with new empirical work.
} 
suggested by $\mathrm{HH}$ in their original paper has never been applied (see also Waldman (2012)). There is much work on the issue of wage rigidity itself and on the effect of product market shocks on wages, but that research has a completely different focus ${ }^{2}$.

The Harris and Holmstrom paper is by no means old and forgotten. In August 2014, it had 161 citations on RePEc, with annual citations substantially increasing after the late 1990's. Just a quick scan of the citations in the last 10 years (2004 and later) reveals its status of a classic. It is cited in many working papers, including those in NBER and IZA series, by leading authors in the field (e.g. Acemoglu, Gibbons, Ichino, Katz, Meghir, Saez) and in top-ranked journals ${ }^{3}$. The model is simply accepted as part of the theoretical literature. For example, Low, Meghir and Pistaferi (2010, p 1441) state without any reservation in the American Economic Review: "We assume that there is no commitment from the side of the firm (or the worker), so Milton Harris and Bengt Holmstrom (1982)-type contracts are not implementable." Or, as Shi $(2009,563)$ notes in Econometrica: "Although heterogeneity, private information, and learning about productivity are important for wage dynamics and turnover in reality, as modeled by Jovanovic (1979), Harris and Holmstrom (1982), and Moscarini (2005), abstracting from them enables me to focus on search". The HarrisHolmstrom model has the status of received (theoretical) wisdom in wage contract theory, as a case of symmetric but incomplete information and learning (see the survey by Chiappori and Salanié (2002).

We introduce our test of the $\mathrm{HH}$ model in section 2 . Section 3 describes the data, 4 presents results on wage rigidity, 5 gives our estimations, 6 discusses human capital investment as an alternative explanation and 7 concludes.

\section{Implementing the Harris-Holmstrom test.}

Our aim is quite simply to apply the test as prescribed in the HH paper: relate the wages of new hires to the variance of wages for experienced workers in the same class, with experience sufficiently long to reveal ability. Portuguese data provide a unique opportunity for this test: panel data covering all workers in the private sector in firms with at least one employee. But even here, as usual, the real world data do not unequivocally match the clean controllable world of theoretical analysis.

\footnotetext{
2 See for example Baker, Gibbs and Holmstrom (1994) on downward rigidity and Guiso, Pistaferri and Schivardi (2005) on the effect of shocks to firms' value added on workers' wages. These papers also give further references on the topics.

${ }^{3}$ E.g. 7 quotes in Journal of Labor Economics, 2 in American Economic Review, 2 in Econometrica, 3 in Journal of Monetary Economics.
} 
In $\mathrm{HH}^{\prime}$ s model, all firms are identical and workers never leave a firm. In a static world, the latter assumption gives the employer first-hand information on the ability distribution in the pool of workers he hires from. In practice, we can not restrict the test to cohorts of workers entering a given firm, as this would rule out all small firms: calculating their own later wage variance would be subject to large measurement error in ability variance. Even for large firms it would not be justified to restrict the data on wage variance for experienced workers to employees that never leave the firm where they start their career: workers who later leave are an integral part of the cohort of entrants, and their departure may well be systematically related to their productivity. Thus, we will aim for measuring the wage dispersion of a given cohort of entrants as experienced workers no matter where they are found working. Restricting observations to workers that never leave the firm is not necessary: employers can observe where workers go when they leave the firm, and note job level and (approximate) pay. When ability (or productivity) is revealed elsewhere in the labour force, employers will certainly have access to indicators of this value. In this case we can indeed follow $\mathrm{HH}$ and look for later variance in the relevant initial population, wherever they have moved.

The phrasing and setting of $\mathrm{HH}$ suggest to use panel data: relate starting wages to the variance of wages in the same group of workers after they have sufficient experience to observe their true ability. This is exactly what we set out to do. But we will never be able to track down the full population. First, there will be attrition due to imperfections in the process of data collection. Fortunately, we can mitigate the problem of attrition in our labour market survey by also using administrative data from social security records. Second, there will be systematic reasons why we do not observe some experienced workers. Workers may be permanently or temporalily absent from paid employment: unemployment, sickness, disability, parental leave, exit from the labour force. For absence with some social security benefit, we can at least control for absence status from the the social security records. For nonparticipants we have no records at all, and hence we cannot distinguish between attrition due to imperfect registration and deliberate exit from the labour force. Labour force exit may bias our measure of variance, but the direction is hard to predict: it may be positive selection (a career or marriage leading to sufficient wealth), negative selection (potential wage too low) or exogenous causes (winning the lottery).

Instead of using panel data, one may also use cross-section data: relate starting wages to wage variance observed simultaneously for a similar group of workers with sufficient experience. In the static world of the $\mathrm{HH}$ model, the two methods would be equivalent and one can indeed read the $\mathrm{HH}$ recipe for testing also as refererring to cross-section data. With cross-section data, larger sample sizes become available, 
but the drawback is of course that there may be relevant unobserved heterogeneity among cohorts. We will use both panel and cross-section data.

An issue not dealt with by $\mathrm{HH}$ but always relevant is the possible explanation of the observations by a competing theory. In this case, human capital theory is a potential alternative. Human capital theory predicts reduced starting wages from the cost of investment in on-the-job training charged to the worker. If investments are higher for worker categories with larger ability dispersion, this would lead to lower starting wages and with the higher ability dispersion showing up in higher wage dispersion for experienced workers, we would observe the same negative relationship as $\mathrm{HH}$ predict. As higher human capital investment will also lead to higher wage growth, we can check this explanation by relating wage growth over the observation period to wage variance for experienced workers. If they are significantly related, lower starting wages can be explained from a higher insurance premium for higher ability variance as well as from higher deductions for investment in on-the-job training. A second way to distinguish the alternative explanations is to consider the development of wage dispersion. $\mathrm{HH}$ predict that the variance of wages will increase as true individual ability comes to replace estimated average ability as a determinant of wages. Human capital theory as specified by Mincer (1974) predicts that the variance will initially decrease, until the overtaking point around age 30-35, and then increase again: differences in intensity of investment in on-the-job training will generate an extra element of wage dispersion that will shrink as the investment fractions decline with advancing experience ${ }^{4}$. In the $\mathrm{HH}$ model, workers start with a uniform wage with uniform deduction for group risk, in the human capital model workers start with different wage deductions as they have different investment intensities. This distinction between uniform and differing deductions cannot be tested (at least, we will not attempt so), as the claim of uniform starting wages abstracts from many unobservable differences among individuals and the remaining claim of larger dispersion of starting wages according to human capital theory than according to $\mathrm{HH}^{\prime} \mathrm{s}$ theory is no meaningful target for empirical testing. But differences in the age (experience) profile are amenable to testing and we will indeed do so.

The $\mathrm{HH}$ prediction concerns a relationship between mean and variance of the distribution of wages. There exists some notion that mean and dispersion are intrinsically positively related. To be more precise on this suspicion, let's suppose that a worker has only one of two possible skills, making blue paintings or red paintings. The levels of skill (number of paintings per month) are denoted by $a_{b}$ and $a_{r}$ respectively and earnings $y$ are found by multiplying by prices $w_{b}$ and $w_{r}$. Let's

\footnotetext{
${ }^{4}$ Polachek (2008) reports support for this U-shaped pattern.
} 
first assume that both skills have equal means $\mu$ and standard deviations $\sigma$. It is then straightforward to derive

$$
E\left(y_{i}\right)=\frac{w_{i} \mu}{w_{i} \sigma} \sigma\left(y_{i}\right)=\frac{\mu}{\sigma} \sigma\left(y_{i}\right), i=b, r
$$

Mean earnings by skill are related linearly to the standard devations by skill. Indeed a mechanical positive relationship as higher value of a skill raises both mean and standard deviation. Now suppose we measure earnings in logs. Then mean log earnings are affected by the skill prices $w_{i}$ but standard deviations are not and we get

$$
E\left(\ln y_{i}\right)=\frac{E\left(\ln w_{i}\right)+\mu}{\sigma} \sigma\left(\ln y_{i}\right)=E\left(\ln w_{i}\right)+\mu
$$

In other words, in logs the mean is independent from the standard deviation, the expected value of the correlation coefficient is zero.

If the skills are not identically distributed, the relationship will be affected by the relation between means and dispersions across skills. As far as we know there is no convincing evidence of a systematic positive or negative relationship at the level of the skills themselves, in terms of real outputs. In fact, there is a nasty measurement problem here for more realistic cases than blue and red paintings: how do you compare output distributions of legal advice and of management performance? Or, at a deeper level, of intellectual versus manual skills? Likewise, there is no compelling evidence that higher priced skills, with higher expected earnings, are also more dispersed in output volume. Hence, we see no reason to expect a systematic bias.

In our robustness tests we also address the socalled reflection problem (Manski 1993). The reflection problem is an identification problem that occurs when an individual outcome is regressed on the mean outcome in the group to which an individual belongs (e.g when individual school performance is related to the average performance of class mates). We argue that the problem is not relevant in our case and offer alternative estimates to support this claim.

We have added an additional variable to represent wage dispersion, viz the skew (third moment about the mean). We did so, as (log) wage distributions are generally not symmetric and as earlier work on compensation for wage risk has shown this to be relevant (Hartog, 2011). None of our results in Table 3 and 4 changes if we exclude skew. It's just a little extra that we will discuss in the assessment of our results. 


\section{Our data}

To test the hypothesis, we use data from the Portuguese Quadros de Pessoal ( $Q P$ ), a longitudinal dataset that covers all workers in firms with at least one employee. The data are gathered annually by the Ministry of Economics, based on an inquiry that every establishment with wage-earners is obliged to fill in under legal obligation. Currently QP annually gathers information in a reference month (October) for more than 300,000 firms and 3 million workers (Portugal has about 10 million inhabitants). Given the mandatory nature of the inquiry and the fact that these data cover all wage earners in the private sector, problems associated with attrition are mitigated.

Collective bargaining in Portugal is dominated by sectoral agreements. In 2005, there were 151 sectoral agreements, 28 multi-firm agreements and 73 single-firm agreements. They covered, respectively, 1016000 workers, 69000 workers and 17 000 workers. 56 collective agreements were extended (Martins, 2014). ${ }^{5}$ There is a national minimum wage, set as a monthly wage for full-time workers. Only handicapped workers and trainees can be paid less, after age specific reductions have been been abandoned in 1999 (Cardoso, Guimaraes, Portugal and Reis, 2014). However, as collective agreements specify wages by finely graded occupations and mandatory extension is widespread, Martins speaks of 30000 de facto minimum wages. However, Cardoso et al. note: "Despite the relevance of collective bargaining, firms have always enjoyed some degree of freedom in wage setting. (....) In fact, once mandatory contract wages have been set, firm-specific arrangements stretch the returns to worker and firm attributes and shrink the returns to union power. Wage cushion therefore leaves ample scope for firm level heterogeneity to influence the wage distribution."(o.c. p 4).

The QP contains detailed information on the workers, including gender, age, schooling, hours worked and monthly earnings split into several components, i.e. base wage, regular payments (e.g. seniority), irregular benefits (e.g. profits and premiums) and overtime payments. The QP also provides detailed information on the firm, such as geographic location, industry and size. The data are provided by the employer, which helps to restrain measurement errors. Civil servants and the selfemployed are not covered by QP.

Initially, we aimed for a 10 year horizon, i.e observe employees from entering a firm at the the start of their working life and follow them for 10 years. Such a choice is arbitrary, but we just felt that 10 years is a reasonable period to let ability differences come to the surface. However, we encountered more sample attrition than we anticipated (we would retain only $38 \%$ ), and we decided to make up for it by combining QP with data from the Social Security Records. From the Social Security

\footnotetext{
${ }^{5}$ Martins does not report the number of workers covered by the extensions.
} 
Records, we observe status in 2006. Social Security Records provide information regarding private and public employment on a monthly basis since January 2000. It is a matched employer-employee census and it excludes firms with individual pension funds and civil servants. The fact that we have an individual and a firm identifier that is common to the identifiers used in Quadros de Pessoal allows us to merge the two sources of information. As the Social Security data have been collected only more recently, we were forced to reduce our observation interval to 6 years, 2000-2006. To the extent possible by data availability we will check for robustness to time interval.

We defined labour market entrants by selecting employees in 2000 with less than 12 months of tenure, with age below or equal to 25 . Tenure below 12 months identifies starters with the firm, the restriction on age identifies labour market entrants ${ }^{6}$. For multiple job holders, we take the job with the highest monthly hours.

\section{(INSERT TABLE 1 ABOUT HERE)}

Our QP base sample in 2000 has almost 90000 starters. In 2006, we observe over 60 000 of them as still employed according to QP. For the other 30000 observations, we only know their status as reported in the Social Security Records. Table 1 gives details on the sample composition. Note that in the end we loose complete track of only $1 \%$ of our starters sample.

To measure the ability distribution in an individual's class, we use education, initial region and initial industry (in 2000). We use a minimum group size to calculate dispersion of 40 observations. In the base specification we use 20 education levels, 4 industries (Manufacturing; Construction; Commerce and Transports; Services) and 5 regions (North, Centro, Lisbon, Alentejo and Algarve), giving us 400 potential groups, reduced to 130 in the panel data and to 142 in the cross-section data om account of the mininum cell size limit. We cannot condition on all the variables observable by the employer (gender, age, region, full detail of education) as we need a decent sample size to calculate variances. Ability dispersion is measured by the variance (and skew) of hourly earnings in 2006 for the class of individuals to which the individual belongs in 2000, i.e. from the 61556 individuals still in the QP sample in 2006. The variables of our analysis have been defined and characterized in the Data Appendix.

\footnotetext{
${ }^{6}$ Initially, we defined labour market entrants by selecting employees in 2000 with less than 12 months of tenure, with potential experience between -3 and +3 years. However, potential experience is defined as age minus years of education minus 6 . This identification of labour market entrants based on their potential experience should have different windows according to the level of education. This identification made us loose around $90 \%$ of the potential yearly number of new labour market entrants, which is around $5 \%$ of the total number of workers (100000).
} 


\section{Wage ridigity}

As HH's claim is a wage premium to prevent wage decline the first step is to check for wage rigidity. For this purpose we use 10 years of our QP panel. In Table 2 the top panel presents data on nominal wage rigidity. A robust and solid check on wage rigidity would require a very detailed inspection of the data, as rigidity refers to absence of wage change if there is no change in any relevant condition of contract or effort: hours worked, job title, job location, fringe benefit entitlement, compensation for disamenities etc should all be constant. Our data do not allow that level of detail in the controls and we must necessarily accept some tolerance of unobserved changes in conditions and other measurement errors. Actually, downward nominal wage rigidity is imposed by law: it is forbidden to reduce wages. Note that this rule does not invalidate $\mathrm{HH}$ but in fact strengthens it: if employers are even forbidden to reduce wages they will surely seek to shift the cost to workers.

Our observations refer to base wage for workers who are still with the same firm in the year indicated as they were initially in 2000. If we allow a nominal wage decline of at most $1 \%$ between two consecutive years, over the entire observation interval $85 \%$ of the wages is downward rigid. Looking at data for separate years, some $80 \%$ of the workers have a wage increase of $1 \%$ or more. Nominal wage declines are surely rare events. Real wage declines (nominal wage increases smaller than the change in the cost of living) are somewhat more frequent, in particular if one considers separate years.

(INSERT TABLE 2 ABOUT HERE)

\section{Results on the wage premium}

\subsection{Base results on panel data}

The $\mathrm{HH}$ prediction concerns a relationship between individual starting wages and group characteristics of the future distribution of experienced wages

$$
y_{i g t}=\alpha \sigma_{y_{g(t+7)}}^{2}+\gamma \text { skew } w_{y_{g(t+7)}}+\beta X_{i t}+\varepsilon_{i g t}
$$

where $y_{i g t}$ represents the hourly total earnings for individual i in year $\mathrm{t}, \sigma_{y_{g(t+7)}}^{2}$ represents the variance of the hourly total earnings for individual $i$ in group $g$ in year t plus 7, skew $w_{y_{g(t+7)}}$ represents the skewness for individual i in group $\mathrm{g}$ in year $\mathrm{t}$ plus 7 , and $X_{i t}$ represents a set of individual characteristics in year t. 
Table 3 gives test results for the panel data set, with starting wages in 2000 and variance and skew for the same sample of individuals in 2006. We start in column (1) with a standard Mincer earnings equation, except that we use age rather than potential experience to estimate lifecycle wage growth, as with potential experience we would loose many observations. Men earn $16 \%$ more than women, wages grow with age by some 3\% per year, in services wages are 6 to $7 \%$ higher than in manufacturing, wages increase substantially with firm size, Lisbon and Alentejo have the highest wages. These results are robust across the analyses we present in this paper and need no more comment. The rate of return to an additional year of schooling, at just over $3 \%$ is quite low, but this is a consequence of our specification. With a standard Mincer equation on the QP data we get $9 \%$ returns on school years and $4 \%$ on experience years, a conventional result for Portugal (Sousa, Portela and Sa 2015) report OLS estimates on the QP for each year from 1986 to 2009 varying between 9 and 10.5\%). The return is cut in half if we restrict the sample to workers 25 years and older, as we do in our testing exercise.

In column (3) we note that variance has a significant positive and skew a significant negative effect on wages, squarely rejecting the $\mathrm{HH}$ prediction. Adding more variables does not affect this result, but the coefficients drop in magnitude (columns (3) - (8)). A noticable drop in magnitude occurs when we measure education with two dummies for three variables (primary, secondary, tertiary) instead of Mincerian years of education. If we use a set of 7 level dummies for education the coefficients differ only marginally from the three-level dummy specification and the same holds if we use a set of 19 dummies to represent both level and type of education (not shown here). In column (8), we add dummies for the employee's status in 2006. Same firm means working in the same firm as in 2000, according to QP; the other dummies reflect status in 2006 recorded by social security administration: receiving unemployment benefit, receiving no benefit, being employed (self-employed, civil servant), or irretrievable. Later social security status has a significant effect on wages, and so does endurance of the employment relation, but inclusion of these variables does not affect the results on variance and skew. Thus, sample attrition from not working in 2006 produces no bias. The result that workers who in 2006 are still employed with the same firm have some 1\% higher wages in 2000 than workers who come to work in a different firm suggests that employers have some additional information on labour market entrants: they can select workers who will appear to stay with them for at least 6 years and pay them higher wages. These workers must be attractive to them. Similarly, temporary or permanent absence from the labour force, or absence from the records, is forshadowed in lower wages. This suggests that employers do have some additional information on their recruits. We will follow 
up on this notion by considering the effect of type of employment contract in section 5.4 .

\subsection{Base results on cross-section data}

The conclusion from following the $\mathrm{HH}$ recipe is thus unequivocal: starting wages are not reduced by an insurance premium for the guarantee that wages will not be reduced if performance turns out to be below standard. To test robustness of this conclusion, we decided to give up the assumption of perfectly forward looking employers, and to calculate variance and skew contemporaneously, by using observations on similar individuals in 2000 who then already had 6-7 years of potential work experience. This allows to use the QP cross-section data and draw on the entire data set, rather than on the 6 year panel data potentially biased by several types of attrition. As noted above, this is not as precise as $\mathrm{HH}$ assume, as the problem of attrition is now replaced by possible differences in unobserved heterogeneity among cohorts 6 years apart. Moreover, variance and skew are now calculated for groups defined by attachment after 6 years of experience rather than at labour market entry: workers may have changed region, industry and firm size. Yet it will also represent information that is more easily available to entrepreneurs as it requires easily available contemporaneous data.

\section{(INSERT TABLE 4 ABOUT HERE)}

As Table 4 shows, the results are essentially unchanged: variance has a significant positive effect, skew a significant negative effect. Controls have remarkably similar effects. The coefficient on the variance is more stable across specifications, except for column (6) for which we have no explanation. With all controls included, the difference in magnitude of the coefficient on variance is quite modest. We can conclude that both panel data and cross-section data lead to the same conclusion: unequivocal rejection of the $\mathrm{HH}$ prediction.

\subsection{Robustness}

In Table 5 we have collected essential results on robustness checks by estimating separately on subgroups, both with panel data and with cross-section data. We distinguish among workers who have stayed with the same firm and workers who have left their firm of entry, and we distinguish among the groups identified in the Social Security records. Essentially the results are unchanged, although in smaller samples precision may be low. The coefficient on variance is no different whether we estimate on stayers, movers or whether we restrict the sample to individuals observed in QP. The latter result indicates that sample attrition is not an issue. 
In addition, we have made several other tests on robustness ${ }^{7}$ :

- Alternative time frames

We have experimented with different time frames and this also showed the results to be robust. Instead of using wage distributions (variances and skew) from 2006 in the wage regression for 2000, we have used wage distributions in 2005 for a wage regression for 1996 and wage distributions in 2009 and 2013 for wage regressions in 2000. We also made additional checks to ensure we really identify first jobs. For the 2000 wage regression with 2006 variance and skew we looked back to 1995 and to 1998 respectively to make sure that individuals did not hold a job already before 2000. All these checks confirmed our basic results.

- Wage floors

We noted above that Portugal has a legal national mimimum wage and that collective agreements set wage floors, mostly by occupation. With an exogenous binding legal minimum wage, employers cannot adjust the starting wage and hence cannot collect an insurance premium. They can adjust employment to equate the minimum wage to expected productivity minus insurance premium, but this would not be visible in our wage regressions. For observed wages sufficiently above the legal minimum, the legislation should have no disturbing effect.

To eliminate the possibly disturbing effect of the national minimum wage, we dropped all observations with wage rates up to $10 \%$ of the national minimum. Ths has no effect on our results. We also applied quantile regression. Results for quantiles 30 and up confirm our tests with statistically significant coefficients and coefficients themselves increasing in magnitude as we estimate for higher quantiles. The insignificance at the low end of the distribution is precisely what one would expect.

The wage floors in collective agreements are not exogenous, as employers sit at the bargaining table and thus can influence the bargaining outcome. Moreover, as discussed above, employers can pay wages above the bargained minimum, and observations on the wage cushion indicate they do. Results from the quantile regressions already indicate that for quantiles above the $20^{\text {th }}$ the estimation results do not differ from OLS results. We have also estimated wage regressions for the bargained wage and for the wage cushion (actually paid base wage minus bargained wage). The results again support our key conclusions: estimates for bargained wage

\footnotetext{
${ }^{7}$ Test results are available from the authors.
} 
and base wage do not differ, estimates for the wage cushion are significant but have lower coefficient values.

- Coefficient of variation

If we replace the variance by the coefficient of variation or the log of the coefficient of variation, results do not change.

- First employer

If we select workers as age below 30, zero tenure and first employer (instead of tenure below 12 months and age below 25 ), results do not change.

\section{- Fixed effects}

We have computed worker fixed effects in a Mincer regression with age and age squared and tiem dummies, for the entire work force in Portugal (40 million observations between 1986 and 2012). We then calculated variances and skew for our labour markets groups on these fixed effects. Wage regression on variance and skew calculated in this way did no affect the core conclusions. Both in the panel specification and the cross-section specification we find highly significant coefficients.

\subsection{The reflection problem}

There is a potential empirical challenge for a clean identification of a group effect. This empirical challenge is known as the reflection problem: one can not disentangle the effect of a group on the individual from the effect of the individual on the group if both individual and group outcomes are determined simultaneously (Manski, 1993). We argue in this section that this is not really a problem in our case. On top of that, we present an econometric solution that does allow to identify the group effect on the individual.

The reflection problem commonly arises when an individual's outcome is supposed to be related to the group mean. It manifests itself as a regression coefficient equal to 1 (Angrist, 2014). In our case, we relate starting wages in 2000 to variance and skew for the same sample of individuals in 2006. If instead we relate starting wage the later mean and estimate $y_{i g t}=\delta \bar{y}_{g(t+7)}+\varepsilon_{i g t}$ we get a coefficient for $\delta$ that is equal to 0.764 . This gives a mild indication that under our empirical strategy the reflection problem might not be seriously undermining the identification of the group effect.

In Table 4, section 5.2, we changed the identification strategy. We replace the assumption of perfectly forward looking employers by sideward looking employers: they use variance and skew observed in workers who at the time already have 6 
years of experience. These values are set and are not defined on the group of workers for whom we explain starting wages. There cannot be direct reflection effects because the individual does not directly contribute to the group outcome. Under this assumption our results are still robust.

We further note that Brock and Durlauf (2000 and 2001) show that the individual has an effect on the group only when the relationship between the individual outcome and the group outcome is linear. As our outcome of interest of the group is the variance (and skew), rather than the mean, we should not have to worry about the reflection problem . and therefore there could exist potentially a reflection problem.

Still, we know that the variance is a function of the mean, $\sigma_{y_{g}}^{2}=E\left(y_{g}^{2}\right)-\mu_{y_{g}}^{2}$. Just to rest any possible doubts we apply the solution proposed by Gormly and Matson (2011) and Battisti (2013) for the reflection effect. This is possible under the "proportionality" assumption made in Arcidiacono et al (2012) and Altonji et al (2015). We adapt their solution to our case, meaning that the outcome of the group is the variance instead of the mean. Basically, we propose to estimate the individual fixed effect and variance group simultaneously in such a way that the individual fixed effect is removed from the group variance (see Appendix B for details about the estimator and algorithm used). This way our variance is mechanically cleared from any possible reflection effect that came from the individual.

As a first indication, we use information for all workers between 1986 and 2013 and estimate an annual wage equation with annual variances $y_{i g t}=\alpha \sigma_{g t \sim i}^{2}+\beta X_{i t}+\theta_{i}+\varepsilon_{i g t}$ where $\mathrm{x}$ includes age, age square, tenure, tenure square and log of the firm size, year dummies, $\theta_{i}$ is an individual fixed effect and $\sigma_{g t \sim i}^{2}$ is the leave-out variance for group g. We are especially interested in the impact of variance $(\alpha)$ cleared from any reflection effect. $\alpha$ is estimated as 0.414 , with standard deviation 0.020 . This is in the same ballpark as the estimates reported in Table 3. The standard deviation of $\sigma_{g t \sim i}^{2}$ is equal to 0.057 . Thus, for an increase of a standard deviation the wages will increase on average by $2.4 \%$.

To get closer to our analysis we merge our dataset with the results obtained in the exercise above: in the wage equation, we now insert the leave-out wage variance after 7 years of experience as simultaneously estimated with the annual wage equations. Thus, we use the variance cleared from any hypothetical reflection effect. Table 6 replicates the sequence of controls that we used in Table 4 (column 3-8). ${ }^{8}$ Estimated coefficients differ, sometimes substantially, but our basic results are

\footnotetext{
${ }^{8}$ When we exclude the worker fixed effect, the difference in magnitude of the coefficient on variance is quite modest. With all controls included the coefficient is significant and equal to 0.415 .
} 
confirmed: starting wages respond significantly positive to variance and certainly not negatively.

\section{(INSERT TABLE 6 ABOUT HERE)}

\subsection{Do employers use more information?}

Both with panel data and with cross-section data, we noted that starting wages forshadow future status. Essentially workers who turn out to stay with the firm obtain a wage premium right at the start of their career. We figured that this might relate to the different contracts that employers offer their recruits. The data allow us to differentiate among 4 types of contract: without term (a tenured position, $40 \%$ of the sample), fixed term (51\%), temporary substitute (e.g. for a woman on maternity leave, $2 \%)$. We use as reference the residual category of all other contract types (7\%).

\section{(INSERT TABLE 7 ABOUT HERE)}

As Table 7 shows, there are some wage differences by contract, but the most interesting part is the interaction with risk. It turns out that only workers with a tenured position experience a significant wage effect of the variance (and actually also of the skew) in their ability distribution. Those workers that will eventually stay with the firm also get a higher salary at the start. Workers with a temporay contract or hired as a substitute do not see any effect of risk in their starting wage.

The results we found do not suppor the $\mathrm{HH}$ prediction. They do support the hypothesis of risk compensation for workers rather than for employers. As documented in Hartog (2011), one may note that investing in schooling is a risky investment. Potential students do not face a single, certain, wage rate after graduating but rather a wage distribution. Risk averse individuals will only invest in an education if they are compensated for the risk they face, on top of the compensation for the earnings forgone. A host of empirical studies, for several countries, have shown that market wages indeed offer compensation for the financial risk of an education. What's more, wages are reduced in response to skew of the post-graduate earnings distribution. This is exactly what the theory of expected utility maximization predicts. Declining absolute risk aversion implies an appreciation of skew, which means that individuals are willing to take a wage cut for facing a wage distribution with positive skew (Tsiang, 1972). Hence, the positive effect of wage variance and the negative effect of skew on starting wages are directly in line with the models and empirical results surveyed in Hartog (2011). They re-confirm that wages compensate for the uncertainty of the pay-off to an education. 
One can take the argument a step further, by noting, first, that the extent of risk shifting will depend on the magnitudes of the elasticities of supply and demand and second, that two types of risk compete for compensation. Potential students will only invest in an education if they are sufficiently compensated for the uncertainty in the distribution of post-graduate wages. Potential employers will only hire a worker if they can accomodate the risk of unknown abililty of the worker. In Berkhout, Hartog and Van Ophem (2014) we have measured heterogeneity of graduates by the distribution of school grades and indeed found that the risk of unknown productivity is shared by workers and firms depending on sector of economic activity and worker and firm characteristics. Workers on a temporary contract bear a greater share of the risk than workers on other contracts. Our present results on the differences between types of contract are similar. Workers who have been offered a permanent contract (no-term contract) are presumably recognised as more desirable by the employer and their stronger market position pays off in higher compensation for the financial risk of their chosen education.

\section{Human capital investment as an alternative explanation?}

In section 2 we noted that human capital theory may provide an alternative explanation for a negative relationship between starting wage and later wage variance when individuals in groups with high ability variance, for some reason, invest more in in human capital and hence have lower starting wage as investment cost is subtracted from their wage. We envisaged two tests of the human capital interpretation. The first is a test on the prediction of a negative relationship between starting wages and wage growth. If high-variance educations are educations with high investment in on-the-job training, wage growth should relate negatively to the later wage variance. The negative relationship between starting wage and wage variance has already been refuted above. So we may consider the converse of our initial conjecture. If high-variance educations are low-ojt investment educations, we should observe a negative relation between wage growth and variance. But as Table 7 shows, we get the same positive effect on wage growth as on starting wages. The same result obtains if we estimate on all workers rather than on labour market entrants.

\section{(INSERT TABLE 8 ABOUT HERE)}

As a second test, we can check the dynamics of the variance: HH predict increasing variance, human capital predicts a $U$ shape, with minimum around age 35 (we only observe the first part of the trajectory). As Figure 1 shows, the variance clearly increases with advancing experience. This does not support the human capital prediction of initial decline but it does support the $\mathrm{HH}$ prediction. 


\section{Conclusion}

We have tested the prediction by Harris and Holmstrom (1982) that starting wages are reduced by an insurance premium for employers' guarantee not to reduce a worker's wage if productivity is revealed to be below average. We applied, as strictly as we could, the test as indicated by Harris and Holmstrom themselves: measure the uncertainty on productivity by the variance of wages for a cohort of labour market entrants when they have matured into experienced workers. The prediction is unequivocally rejected. The results do support the hypothesis that market wages contain a premium for the uncertainy that students face on their post-graduate wages when they decide on their education. This reinforces earlier empirical results on the latter.

Our conclusion is at variance with a conclusion by Chiappori, Salanié and Valentin (1999) who generalise the HH model to a "class of LDR models": learning and downward rigidity. For such models the authors derive what they call the Late Beginner Property. Consider two workers $A$ and $B$, who start at equal wages in period 0 . In period 1 , A earns more, in period 2 wages are again equal. Hence, $B$ is a late starter, who catches up with $A$, an early starter. Then $B$ has better future prospects. Controlling for the wage at date 2 , the wage at date 1 should be negatively correlated with future wages (at date 3 and beyond). The model is reformulated to allow for a bureacratic firm with a hierarchical structure and wage jumps connected to promotions and then tested on some 1000 highly educated executives in a French state-owned company followed for 15 years. The key prediction of the Late Starter Advantage is supported. The reverse prediction from human capital theory (differences in human capital investment would generate better careers after a slow (wage) start) is rejected, just as in our own test.

The test by Chiappori et al. and our test are hard to compare. Whatever the value of the former test, our results show that the implication claimed by Chiappori et al. is not based on employer behaviour as specified by Harris and Holmstrom. Waldman (2012) notes that the results can be explained by a model where wages equal expected productivity and productivity changes are serially correlated. 
Table 1. Sample composition

\begin{tabular}{lcc} 
& N & $\%$ \\
\hline Starters in QP 2000 & 92996 & 100 \\
Observed in QP 2006 & 61556 & 66 \\
$\quad$ Same firm & 20036 & 22 \\
Different firm & 41520 & 45 \\
& & \\
Not in QP 2006 & 31440 & 34 \\
On unemployment benefit & 3579 & 4 \\
Not receiving any benefit & 20340 & 22 \\
Employed & 6349 & 7 \\
Not in Soc Sec Records & 1172 & 1 \\
\hline
\end{tabular}


Table 2. Base wage rigidity

\begin{tabular}{|c|c|c|c|c|c|}
\hline Nominal (\%) & $\begin{array}{l}\text { Negative } \\
>=-10 \%\end{array}$ & $\begin{array}{c}\text { Negative } \\
>=-10 \%<-1 \%\end{array}$ & $\begin{array}{c}\text { Negative } \\
>=-1 \%<=1 \%\end{array}$ & Positive $>1 \%$ & Total \\
\hline Total & 6 & 9 & 35 & 50 & 100 \\
\hline 2002 & 0 & 0 & 0 & 100 & 100 \\
\hline 2003 & 3 & 2 & 14 & 81 & 100 \\
\hline 2004 & 3 & 2 & 15 & 80 & 100 \\
\hline 2005 & 3 & 2 & 15 & 80 & 100 \\
\hline 2006 & 3 & 2 & 17 & 78 & 100 \\
\hline 2007 & 3 & 2 & 15 & 80 & 100 \\
\hline 2008 & 3 & 2 & 14 & 81 & 100 \\
\hline 2009 & 4 & 13 & 32 & 50 & 100 \\
\hline Tenure 1 year & 1 & 0 & 1 & 98 & 100 \\
\hline Tenure 2 years & 4 & 2 & 16 & 77 & 100 \\
\hline Tenure 3 years & 4 & 2 & 16 & 78 & 100 \\
\hline Tenure 4 years & 3 & 2 & 16 & 78 & 100 \\
\hline Tenure 5 years & 3 & 2 & 17 & 78 & 100 \\
\hline Tenure 6 years & 3 & 2 & 17 & 78 & 100 \\
\hline Tenure 7 years & 3 & 2 & 17 & 77 & 100 \\
\hline Tenure 8 years & 3 & 2 & 17 & 78 & 100 \\
\hline Tenure 9 years & 2 & 2 & 16 & 80 & 100 \\
\hline Without term contract & 3 & 2 & 16 & 79 & 100 \\
\hline Fixed term contract & 3 & 1 & 9 & 87 & 100 \\
\hline Temporary substitute & 1 & 1 & 4 & 94 & 100 \\
\hline Without term contract $(\mathrm{t}=\mathrm{t}-1)$ & 3 & 2 & 15 & 81 & 100 \\
\hline Fixed term contract $(\mathrm{t}=\mathrm{t}-1)$ & 2 & 1 & 8 & 88 & 100 \\
\hline Temporary substitute $(\mathrm{t}=\mathrm{t}-1)$ & 1 & 0 & 3 & 96 & 100 \\
\hline Real(\%) & $\begin{array}{l}\text { Negative } \\
>=-10 \%\end{array}$ & $\begin{array}{c}\text { Negative } \\
>=-10 \%<-1 \%\end{array}$ & $\begin{array}{c}\text { Negative } \\
>=-1 \%<=1 \%\end{array}$ & Positive $>1 \%$ & Total \\
\hline Total & 4 & 18 & 28 & 50 & 100 \\
\hline 2002 & 0 & 0 & 0 & 100 & 100 \\
\hline 2003 & 4 & 20 & 19 & 57 & 100 \\
\hline 2004 & 3 & 17 & 20 & 60 & 100 \\
\hline 2005 & 3 & 17 & 20 & 61 & 100 \\
\hline 2006 & 3 & 32 & 14 & 51 & 100 \\
\hline 2007 & 3 & 17 & 15 & 65 & 100 \\
\hline 2008 & 3 & 1 & 1 & 95 & 100 \\
\hline 2009 & 4 & 3 & 43 & 50 & 100 \\
\hline Tenure 1 year & 1 & 1 & 1 & 97 & 100 \\
\hline Tenure 2 years & 4 & 17 & 12 & 66 & 100 \\
\hline Tenure 3 years & 4 & 18 & 13 & 65 & 100 \\
\hline Tenure 4 years & 4 & 18 & 14 & 64 & 100 \\
\hline Tenure 5 years & 3 & 19 & 15 & 62 & 100 \\
\hline Tenure 6 years & 3 & 20 & 15 & 62 & 100 \\
\hline Tenure 7 years & 3 & 20 & 15 & 61 & 100 \\
\hline Tenure 8 years & 3 & 19 & 15 & 62 & 100 \\
\hline Tenure 9 years & 3 & 19 & 18 & 61 & 100 \\
\hline Without term contract & 3 & 19 & 16 & 62 & 100 \\
\hline Fixed term contract & 3 & 10 & 7 & 80 & 100 \\
\hline Temporary substitute & 1 & 5 & 3 & 91 & 100 \\
\hline Without term contract $(t=t-1)$ & 3 & 17 & 15 & 65 & 100 \\
\hline Fixed term contract $(t=t-1)$ & 2 & 9 & 7 & 82 & 100 \\
\hline Temporary substitute $(\mathrm{t}=\mathrm{t}-1)$ & 1 & 3 & 2 & 94 & 100 \\
\hline
\end{tabular}


Table 3. Base regression results

\begin{tabular}{|c|c|c|c|c|c|c|c|c|}
\hline & (1) & (2) & (3) & (4) & (5) & (6) & (7) & (8) \\
\hline Variance & & & $\begin{array}{c}0.875^{\star * *} \\
(0.211)\end{array}$ & $\begin{array}{c}0.901^{* * *} \\
(0.199)\end{array}$ & $\begin{array}{c}0.774^{* * *} \\
(0.159)\end{array}$ & $\begin{array}{c}0.483^{* * *} \\
(0.147)\end{array}$ & $\begin{array}{c}0.302^{* * *} \\
(0.089)\end{array}$ & $\begin{array}{c}0.302^{* * *} \\
(0.088)\end{array}$ \\
\hline Skewness & & & $\begin{array}{c}-0.036^{\star *} \\
(0.015)\end{array}$ & $\begin{array}{c}-0.052^{* * *} \\
(0.016)\end{array}$ & $\begin{array}{c}-0.042^{* \star *} \\
(0.012)\end{array}$ & $\begin{array}{l}-0.018^{* *} \\
(0.009)\end{array}$ & $\begin{array}{l}-0.009^{*} \\
(0.005)\end{array}$ & $\begin{array}{l}-0.009^{*} \\
(0.005)\end{array}$ \\
\hline Male & $\begin{array}{l}0.159^{* * *} \\
(0.008)\end{array}$ & $\begin{array}{l}0.161^{* * *} \\
(0.007)\end{array}$ & $\begin{array}{c}0.152^{* * *} \\
(0.009)\end{array}$ & $\begin{array}{c}0.167^{* * *} \\
(0.009)\end{array}$ & $\begin{array}{l}0.162^{* * *} \\
(0.007)\end{array}$ & $\begin{array}{l}0.160^{* * *} \\
(0.007)\end{array}$ & $\begin{array}{l}0.161^{* * *} \\
(0.007)\end{array}$ & $\begin{array}{c}0.161^{* * *} \\
(0.007)\end{array}$ \\
\hline Age & $\begin{array}{l}0.037^{\star * *} \\
(0.002)\end{array}$ & $\begin{array}{c}0.033^{* * *} \\
(0.001)\end{array}$ & $\begin{array}{c}0.034^{\star * *} \\
(0.002)\end{array}$ & $\begin{array}{c}0.033^{* * *} \\
(0.002)\end{array}$ & $\begin{array}{l}0.033^{\star * *} \\
(0.001)\end{array}$ & $\begin{array}{l}0.032^{\star * *} \\
(0.001)\end{array}$ & $\begin{array}{c}0.030^{* * *} \\
(0.001)\end{array}$ & $\begin{array}{c}0.029^{* * *} \\
(0.001)\end{array}$ \\
\hline Age square & $\begin{array}{c}-0.000^{\star \star \star} \\
(0.000)\end{array}$ & $\begin{array}{c}-0.000^{* * *} \\
(0.000)\end{array}$ & $\begin{array}{c}-0.000^{* * \star} \\
(0.000)\end{array}$ & $\begin{array}{c}-0.000^{\star * *} \\
(0.000)\end{array}$ & $\begin{array}{c}-0.000^{\star \star \star} \\
(0.000)\end{array}$ & $\begin{array}{c}-0.000^{* \star *} \\
(0.000)\end{array}$ & $\begin{array}{c}-0.000^{* * *} \\
(0.000)\end{array}$ & $\begin{array}{c}-0.000^{* * *} \\
(0.000)\end{array}$ \\
\hline Construction & & $\begin{array}{l}0.029^{* *} \\
(0.014)\end{array}$ & & $\begin{array}{c}-0.097^{\star \star *} \\
(0.021)\end{array}$ & $\begin{array}{l}-0.020 \\
(0.019)\end{array}$ & $\begin{array}{l}-0.001 \\
(0.014)\end{array}$ & $\begin{array}{c}0.006 \\
(0.010)\end{array}$ & $\begin{array}{c}0.009 \\
(0.009)\end{array}$ \\
\hline Commerce, Tourism, & & & & & & & & \\
\hline Transportation & & $\begin{array}{c}0.013 \\
(0.010)\end{array}$ & & $\begin{array}{c}-0.057^{\star * *} \\
(0.018)\end{array}$ & $\begin{array}{l}-0.008 \\
(0.014)\end{array}$ & $\begin{array}{l}-0.007 \\
(0.012)\end{array}$ & $\begin{array}{c}0.010 \\
(0.009)\end{array}$ & $\begin{array}{c}0.011 \\
(0.009)\end{array}$ \\
\hline Services & & $\begin{array}{l}0.074^{\star * *} \\
(0.015)\end{array}$ & & $\begin{array}{l}0.053^{* \star} \\
(0.024)\end{array}$ & $\begin{array}{c}0.065^{\star \star \star} \\
(0.017)\end{array}$ & $\begin{array}{c}0.056^{\star \star *} \\
(0.015)\end{array}$ & $\begin{array}{c}0.056^{\star \star *} \\
(0.011)\end{array}$ & $\begin{array}{c}0.056^{\star \star \star} \\
(0.011)\end{array}$ \\
\hline Medium firm (size) & & $\begin{array}{l}0.146^{* * *} \\
(0.009)\end{array}$ & & & $\begin{array}{c}0.149^{* * *} \\
(0.009)\end{array}$ & $\begin{array}{l}0.146^{\star * *} \\
(0.009)\end{array}$ & $\begin{array}{c}0.145^{\star \star *} \\
(0.009)\end{array}$ & $\begin{array}{c}0.144^{* * *} \\
(0.009)\end{array}$ \\
\hline Large firm (size) & & $\begin{array}{l}0.237^{* * *} \\
(0.007)\end{array}$ & & & $\begin{array}{l}0.252^{* * *} \\
(0.007)\end{array}$ & $\begin{array}{l}0.238^{* * *} \\
(0.007)\end{array}$ & $\begin{array}{c}0.244^{* * *} \\
(0.007)\end{array}$ & $\begin{array}{c}0.243^{* * *} \\
(0.007)\end{array}$ \\
\hline Center & & $\begin{array}{l}0.024^{*} \\
(0.013)\end{array}$ & & & & $\begin{array}{c}0.013 \\
(0.013)\end{array}$ & $\begin{array}{l}0.023^{*} \\
(0.013)\end{array}$ & $\begin{array}{l}0.023^{*} \\
(0.013)\end{array}$ \\
\hline Lisbon & & $\begin{array}{l}0.117^{* * *} \\
(0.011)\end{array}$ & & & & $\begin{array}{l}0.090^{* * *} \\
(0.012)\end{array}$ & $\begin{array}{l}0.099^{* * *} \\
(0.010)\end{array}$ & $\begin{array}{c}0.099^{* * *} \\
(0.010)\end{array}$ \\
\hline Alentejo & & $\begin{array}{l}0.083^{* * *} \\
(0.013)\end{array}$ & & & & $\begin{array}{l}0.069^{* * *} \\
(0.013)\end{array}$ & $\begin{array}{c}0.084^{* * *} \\
(0.014)\end{array}$ & $\begin{array}{c}0.084^{* * *} \\
(0.014)\end{array}$ \\
\hline Algarve & & $\begin{array}{c}0.003 \\
(0.012)\end{array}$ & & & & $\begin{array}{l}0.007 \\
(0.012)\end{array}$ & $\begin{array}{c}0.010 \\
(0.011)\end{array}$ & $\begin{array}{c}0.009 \\
(0.011)\end{array}$ \\
\hline Upper Secondary & & & & & & & $\begin{array}{l}0.091^{* * *} \\
(0.010)\end{array}$ & $\begin{array}{c}0.089^{* * *} \\
(0.010)\end{array}$ \\
\hline Bachelor or more & & & & & & & $\begin{array}{c}0.537^{* * *} \\
(0.033)\end{array}$ & $\begin{array}{c}0.533^{* * *} \\
(0.033)\end{array}$ \\
\hline Same firm & & & & & & & & $\begin{array}{c}0.011 \\
(0.007)\end{array}$ \\
\hline SSR UB & & & & & & & & $\begin{array}{c}-0.015^{* \star *} \\
(0.005)\end{array}$ \\
\hline SSR No Benefit & & & & & & & & $\begin{array}{c}-0.024^{* \star *} \\
(0.003)\end{array}$ \\
\hline SSR Employed & & & & & & & & $\begin{array}{c}-0.012^{* *} \\
(0.005)\end{array}$ \\
\hline SSR Lost & & & & & & & & $\begin{array}{c}-0.041^{\star \star *} \\
(0.007)\end{array}$ \\
\hline Years of Education & $\begin{array}{l}0.033^{* * *} \\
(0.004)\end{array}$ & $\begin{array}{l}0.022 * * * \\
(0.002)\end{array}$ & $\begin{array}{c}0.022^{* * *} \\
(0.004)\end{array}$ & $\begin{array}{c}0.018^{* * *} \\
(0.003)\end{array}$ & $\begin{array}{l}0.016^{\star * *} \\
(0.003)\end{array}$ & $\begin{array}{l}0.018^{* * *} \\
(0.002)\end{array}$ & & \\
\hline Constant & $\begin{array}{c}-1.140^{* * *} \\
(0.059)\end{array}$ & $\begin{array}{c}-1.157^{\star * *} \\
(0.041)\end{array}$ & $\begin{array}{c}-1.087^{* * *} \\
(0.063)\end{array}$ & $\begin{array}{c}-0.986^{\star * *} \\
(0.061)\end{array}$ & $\begin{array}{c}-1.107^{\star * *} \\
(0.050)\end{array}$ & $\begin{array}{c}-1.138^{\star * *} \\
(0.045)\end{array}$ & $\begin{array}{c}-0.959^{* * *} \\
(0.037)\end{array}$ & $\begin{array}{c}-0.949^{* * *} \\
(0.036)\end{array}$ \\
\hline Observations & 92,996 & 92,996 & 92,996 & 92,996 & 92,996 & 92,996 & 92,996 & 92,996 \\
\hline R-squared & 0.170 & 0.298 & 0.188 & 0.204 & 0.293 & 0.301 & 0.318 & 0.319 \\
\hline
\end{tabular}

Notes: OLS baseline results using hourly total earnings as the dependent variable. Cluster (by group) standard errors in parentheses where ${ }^{* * *} \mathrm{p}<0.01, * * \mathrm{p}<0.05,{ }^{*} \mathrm{p}<0.1$. 
Table 4. Cross section results

\begin{tabular}{|c|c|c|c|c|c|c|c|c|}
\hline & (1) & (2) & (3) & (4) & (5) & (6) & (7) & (8) \\
\hline Variance & & & $\begin{array}{l}0.915^{\star \star *} \\
(0.167)\end{array}$ & $\begin{array}{l}0.944^{* * *} \\
(0.216)\end{array}$ & $\begin{array}{l}0.577^{\star * *} \\
(0.202)\end{array}$ & $\begin{array}{l}0.010 \\
(0.242)\end{array}$ & $\begin{array}{c}0.337^{\star \star *} \\
(0.102)\end{array}$ & $\begin{array}{c}0.331^{* * *} \\
(0.101)\end{array}$ \\
\hline Skewness & & & $\begin{array}{c}-0.067^{\star \star *} \\
(0.023)\end{array}$ & $\begin{array}{c}-0.057^{\star \star *} \\
(0.017)\end{array}$ & $\begin{array}{c}-0.045^{\star \star \star} \\
(0.014)\end{array}$ & $\begin{array}{c}-0.022^{\star *} \\
(0.011)\end{array}$ & $\begin{array}{c}-0.020^{\star *} \\
(0.010)\end{array}$ & $\begin{array}{c}-0.020^{\star *} \\
(0.009)\end{array}$ \\
\hline Male & $\begin{array}{l}0.161^{* * *} \\
(0.008)\end{array}$ & $\begin{array}{l}0.161^{* * *} \\
(0.007)\end{array}$ & $\begin{array}{l}0.159^{* * *} \\
(0.009)\end{array}$ & $\begin{array}{l}0.165^{\star * *} \\
(0.009)\end{array}$ & $\begin{array}{l}0.161^{* * *} \\
(0.007)\end{array}$ & $\begin{array}{l}0.160^{* * *} \\
(0.007)\end{array}$ & $\begin{array}{l}0.161^{* * *} \\
(0.007)\end{array}$ & $\begin{array}{c}0.160^{\star * *} \\
(0.007)\end{array}$ \\
\hline Age & $\begin{array}{l}0.037^{* * *} \\
(0.002)\end{array}$ & $\begin{array}{l}0.032^{* * *} \\
(0.002)\end{array}$ & $\begin{array}{l}0.034^{* * *} \\
(0.002)\end{array}$ & $\begin{array}{l}0.034^{* * *} \\
(0.002)\end{array}$ & $\begin{array}{l}0.034^{* * *} \\
(0.002)\end{array}$ & $\begin{array}{l}0.033^{* * *} \\
(0.002)\end{array}$ & $\begin{array}{l}0.030^{* * *} \\
(0.001)\end{array}$ & $\begin{array}{l}0.030^{* * *} \\
(0.001)\end{array}$ \\
\hline Age square & $\begin{array}{c}-0.000^{* \star *} \\
(0.000)\end{array}$ & $\begin{array}{c}-0.000^{* * *} \\
(0.000)\end{array}$ & $\begin{array}{c}-0.000^{\star * *} \\
(0.000)\end{array}$ & $\begin{array}{c}-0.000^{* * *} \\
(0.000)\end{array}$ & $\begin{array}{c}-0.000^{* * *} \\
(0.000)\end{array}$ & $\begin{array}{c}-0.000^{* \star *} \\
(0.000)\end{array}$ & $\begin{array}{c}-0.000^{* * *} \\
(0.000)\end{array}$ & $\begin{array}{c}-0.000^{* \star *} \\
(0.000)\end{array}$ \\
\hline Construction & & $\begin{array}{l}0.035^{\star \star} \\
(0.015)\end{array}$ & & $\begin{array}{l}-0.035 \\
(0.022)\end{array}$ & $\begin{array}{c}0.032 \\
(0.021)\end{array}$ & $\begin{array}{l}0.034^{* *} \\
(0.016)\end{array}$ & $\begin{array}{l}0.023^{\star *} \\
(0.009)\end{array}$ & $\begin{array}{c}0.026^{\star \star \star} \\
(0.009)\end{array}$ \\
\hline $\begin{array}{l}\text { Commerce, Tourism, } \\
\text { Transportation }\end{array}$ & & $\begin{array}{c}0.012 \\
(0.010)\end{array}$ & & $\begin{array}{c}-0.046^{* *} \\
(0.020)\end{array}$ & $\begin{array}{c}0.010 \\
(0.018)\end{array}$ & $\begin{array}{c}0.012 \\
(0.013)\end{array}$ & $\begin{array}{c}0.010 \\
(0.008)\end{array}$ & $\begin{array}{c}0.010 \\
(0.008)\end{array}$ \\
\hline Services & & $\begin{array}{l}0.073^{\star \star *} \\
(0.015)\end{array}$ & & $\begin{array}{c}0.032 \\
(0.025)\end{array}$ & $\begin{array}{l}0.062^{* * *} \\
(0.022)\end{array}$ & $\begin{array}{l}0.069^{* * *} \\
(0.017)\end{array}$ & $\begin{array}{l}0.042^{* * *} \\
(0.014)\end{array}$ & $\begin{array}{c}0.043^{\star * *} \\
(0.014)\end{array}$ \\
\hline Medium firm (size) & & $\begin{array}{c}0.146^{\star \star *} \\
(0.010)\end{array}$ & & & $\begin{array}{c}0.147^{\star \star *} \\
(0.010)\end{array}$ & $\begin{array}{c}0.146^{\star \star *} \\
(0.010)\end{array}$ & $\begin{array}{c}0.144^{* \star *} \\
(0.010)\end{array}$ & $\begin{array}{c}0.144^{\star * *} \\
(0.010)\end{array}$ \\
\hline Large firm (size) & & $\begin{array}{l}0.238^{* \star *} \\
(0.007)\end{array}$ & & & $\begin{array}{l}0.247^{* * *} \\
(0.008)\end{array}$ & $\begin{array}{l}0.238^{* * *} \\
(0.007)\end{array}$ & $\begin{array}{l}0.243^{* * *} \\
(0.007)\end{array}$ & $\begin{array}{c}0.242^{* * *} \\
(0.007)\end{array}$ \\
\hline Center & & $\begin{array}{c}0.022 \\
(0.013)\end{array}$ & & & & $\begin{array}{c}0.017 \\
(0.014)\end{array}$ & $\begin{array}{l}0.020^{* *} \\
(0.010)\end{array}$ & $\begin{array}{l}0.020^{* *} \\
(0.010)\end{array}$ \\
\hline Lisbon & & $\begin{array}{l}0.115^{\star \star *} \\
(0.010)\end{array}$ & & & & $\begin{array}{l}0.105^{\star \star *} \\
(0.018)\end{array}$ & $\begin{array}{l}0.084^{\star * *} \\
(0.011)\end{array}$ & $\begin{array}{c}0.085^{\star * *} \\
(0.011)\end{array}$ \\
\hline Alentejo & & $\begin{array}{l}0.086^{* * *} \\
(0.013)\end{array}$ & & & & $\begin{array}{l}0.087^{* * *} \\
(0.014)\end{array}$ & $\begin{array}{l}0.091^{* * *} \\
(0.012)\end{array}$ & $\begin{array}{c}0.091^{* * *} \\
(0.012)\end{array}$ \\
\hline Algarve & & $\begin{array}{c}0.008 \\
(0.012)\end{array}$ & & & & $\begin{array}{c}0.005 \\
(0.014)\end{array}$ & $\begin{array}{c}0.011 \\
(0.009)\end{array}$ & $\begin{array}{c}0.010 \\
(0.009)\end{array}$ \\
\hline Upper Secondary & & & & & & & $\begin{array}{l}0.090^{* * *} \\
(0.010)\end{array}$ & $\begin{array}{l}0.088^{* * *} \\
(0.010)\end{array}$ \\
\hline Bachelor or more & & & & & & & $\begin{array}{l}0.558^{\star \star *} \\
(0.036)\end{array}$ & $\begin{array}{c}0.554^{\star * *} \\
(0.036)\end{array}$ \\
\hline Same firm & & & & & & & & $\begin{array}{c}0.011 \\
(0.007)\end{array}$ \\
\hline SSR UB & & & & & & & & $\begin{array}{c}-0.013^{* * *} \\
(0.005)\end{array}$ \\
\hline SSR No Benefit & & & & & & & & $\begin{array}{c}-0.023^{* * *} \\
(0.003)\end{array}$ \\
\hline SSR Employed & & & & & & & & $\begin{array}{l}-0.011^{* *} \\
(0.005)\end{array}$ \\
\hline SSR Lost & & & & & & & & $\begin{array}{c}-0.038^{* * *} \\
(0.007)\end{array}$ \\
\hline Years of Education & $\begin{array}{l}0.032^{* * *} \\
(0.004)\end{array}$ & $\begin{array}{l}0.022^{* * *} \\
(0.002)\end{array}$ & $\begin{array}{l}0.015^{\star \star *} \\
(0.004)\end{array}$ & $\begin{array}{l}0.015^{* * *} \\
(0.003)\end{array}$ & $\begin{array}{l}0.015^{\star \star *} \\
(0.003)\end{array}$ & $\begin{array}{l}0.021^{* * *} \\
(0.003)\end{array}$ & & \\
\hline Constant & $\begin{array}{c}-1.132^{\star \star *} \\
(0.062)\end{array}$ & $\begin{array}{c}-1.149^{* \star *} \\
(0.042)\end{array}$ & $\begin{array}{c}-1.002^{\star * *} \\
(0.054)\end{array}$ & $\begin{array}{c}-0.994^{\star \star *} \\
(0.057)\end{array}$ & $\begin{array}{c}-1.104^{\star \star *} \\
(0.049)\end{array}$ & $\begin{array}{c}-1.109^{\star \star *} \\
(0.043)\end{array}$ & $\begin{array}{c}-0.949^{\star * *} \\
(0.033)\end{array}$ & $\begin{array}{c}-0.939^{\star \star *} \\
(0.032)\end{array}$ \\
\hline Observations & 89,417 & 89,417 & 89,417 & 89,417 & 89,417 & 89,417 & 89,417 & 89,417 \\
\hline R-squared & 0.168 & 0.297 & 0.197 & 0.204 & 0.288 & 0.298 & 0.316 & 0.317 \\
\hline
\end{tabular}

${ }_{* \star *} p<0.01,{ }^{* *} p<0.05,{ }^{*} p<0.1$

Table 5. Sample attrition results

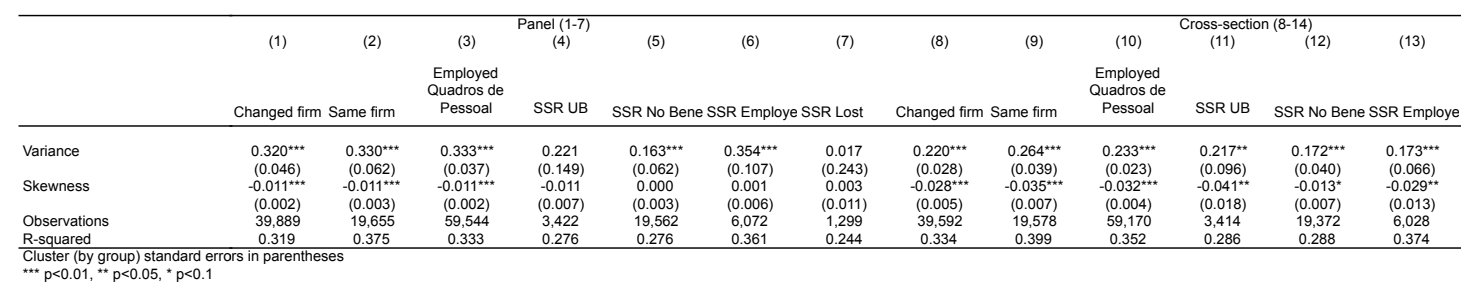


Table 6. The reflection problem

\begin{tabular}{|c|c|c|c|c|c|c|}
\hline VARIABLES & (3) & (4) & (5) & (6) & (7) & $(8)$ \\
\hline variance no reflection & $\begin{array}{c}0.801^{* * *} \\
(0.021)\end{array}$ & $\begin{array}{c}0.710^{* * *} \\
(0.024)\end{array}$ & $\begin{array}{c}0.348^{\star \star *} \\
(0.023)\end{array}$ & $\begin{array}{l}0.112^{\star * *} \\
(0.028)\end{array}$ & $\begin{array}{l}0.149^{\star * *} \\
(0.027)\end{array}$ & $\begin{array}{c}0.148^{\star * *} \\
(0.027)\end{array}$ \\
\hline skewness cross-section & $\begin{array}{c}-0.034^{* * *} \\
(0.002)\end{array}$ & $\begin{array}{c}-0.040^{* * *} \\
(0.002)\end{array}$ & $\begin{array}{c}-0.024^{\star * *} \\
(0.002)\end{array}$ & $\begin{array}{c}-0.009^{* * *} \\
(0.002)\end{array}$ & $\begin{array}{c}-0.009^{\star * *} \\
(0.002)\end{array}$ & $\begin{array}{c}-0.009^{* * *} \\
(0.002)\end{array}$ \\
\hline Worker fixed effect without reflection & $\begin{array}{c}0.688^{\star \star \star} \\
(0.003)\end{array}$ & $\begin{array}{c}0.689^{* * *} \\
(0.003)\end{array}$ & $\begin{array}{c}0.676^{\star \star \star} \\
(0.003)\end{array}$ & $\begin{array}{l}0.674^{\star * *} \\
(0.003)\end{array}$ & $\begin{array}{c}0.664^{\star \star *} \\
(0.003)\end{array}$ & $\begin{array}{c}0.666^{\star \star \star} \\
(0.003)\end{array}$ \\
\hline Observations & 92,986 & 92,986 & 92,986 & 92,986 & 92,986 & 92,986 \\
\hline R-squared & 0.487 & 0.492 & 0.556 & 0.558 & 0.559 & 0.559 \\
\hline
\end{tabular}

${ }^{* * *} p<0.01,{ }^{* *} p<0.05,{ }^{*} p<0.1$

Table 7. Analysis by contract type

\begin{tabular}{|c|c|c|c|c|c|c|c|c|}
\hline & (1) & (2) & (3) & (4) & (5) & (6) & (7) & $(8)$ \\
\hline Variance & $\begin{array}{l}0.297^{\star \star \star} \\
(0.033)\end{array}$ & $\begin{array}{c}0.298^{* * *} \\
(0.033)\end{array}$ & $\begin{array}{c}0.219^{* * *} \\
(0.079)\end{array}$ & $\begin{array}{l}0.224^{* * *} \\
(0.083)\end{array}$ & $\begin{array}{c}0.296^{* * *} \\
(0.033)\end{array}$ & $\begin{array}{l}0.297^{\star \star \star *} \\
(0.033)\end{array}$ & $\begin{array}{l}0.220^{* \star \star} \\
(0.079)\end{array}$ & $\begin{array}{c}0.222^{* \star *} \\
(0.084)\end{array}$ \\
\hline Skewness & $\begin{array}{c}-0.008^{* * *} \\
(0.001)\end{array}$ & $\begin{array}{c}-0.008^{\star * *} \\
(0.001)\end{array}$ & $\begin{array}{c}-0.007^{\star \star *} \\
(0.001)\end{array}$ & $\begin{array}{l}-0.007^{*} \\
(0.003)\end{array}$ & $\begin{array}{c}-0.008^{* * *} \\
(0.001)\end{array}$ & $\begin{array}{c}-0.007^{\star * *} \\
(0.001)\end{array}$ & $\begin{array}{c}-0.007^{\star * *} \\
(0.001)\end{array}$ & $\begin{array}{c}-0.007^{\star *} \\
(0.003)\end{array}$ \\
\hline Male & $\begin{array}{l}0.162^{* * *} \\
(0.002)\end{array}$ & $\begin{array}{l}0.163^{\star * *} \\
(0.002)\end{array}$ & $\begin{array}{c}0.163^{* * *} \\
(0.002)\end{array}$ & $\begin{array}{c}0.163^{* * *} \\
(0.002)\end{array}$ & $\begin{array}{l}0.161^{* * *} \\
(0.002)\end{array}$ & $\begin{array}{l}0.162^{* * *} \\
(0.002)\end{array}$ & $\begin{array}{l}0.162^{* * *} \\
(0.002)\end{array}$ & $\begin{array}{l}0.162^{* * \star} \\
(0.002)\end{array}$ \\
\hline Age & $\begin{array}{l}0.025^{\star \star *} \\
(0.001)\end{array}$ & $\begin{array}{l}0.025^{\star \star \star} \\
(0.001)\end{array}$ & $\begin{array}{l}0.025^{\star \star \star} \\
(0.001)\end{array}$ & $\begin{array}{c}0.025^{\star \star \star} \\
(0.001)\end{array}$ & $\begin{array}{l}0.024^{* \star *} \\
(0.001)\end{array}$ & $\begin{array}{l}0.024^{* \star *} \\
(0.001)\end{array}$ & $\begin{array}{l}0.024^{\star \star *} \\
(0.001)\end{array}$ & $\begin{array}{l}0.024^{\star \star \star \star} \\
(0.001)\end{array}$ \\
\hline Age squared & $\begin{array}{c}-0.000^{* * *} \\
(0.000)\end{array}$ & $\begin{array}{c}-0.000^{\star \star *} \\
(0.000)\end{array}$ & $\begin{array}{c}-0.000^{* \star *} \\
(0.000)\end{array}$ & $\begin{array}{c}-0.000^{* \star *} \\
(0.000)\end{array}$ & $\begin{array}{c}-0.000^{* * *} \\
(0.000)\end{array}$ & $\begin{array}{c}-0.000^{* * *} \\
(0.000)\end{array}$ & $\begin{array}{c}-0.000^{* * *} \\
(0.000)\end{array}$ & $\begin{array}{c}-0.000^{* * *} \\
(0.000)\end{array}$ \\
\hline Construction & $\begin{array}{l}0.008^{\star *} \\
(0.004)\end{array}$ & $\begin{array}{l}0.008^{\star *} \\
(0.004)\end{array}$ & $\begin{array}{l}0.008^{\star *} \\
(0.004)\end{array}$ & $\begin{array}{l}0.008^{\star *} \\
(0.004)\end{array}$ & $\begin{array}{l}0.011^{\star \star \star} \\
(0.004)\end{array}$ & $\begin{array}{l}0.011^{* * *} \\
(0.004)\end{array}$ & $\begin{array}{l}0.011^{* * *} \\
(0.004)\end{array}$ & $\begin{array}{c}0.011^{* * *} \\
(0.004)\end{array}$ \\
\hline Commerce, Tourism, Transportation & $\begin{array}{l}0.013^{\star \star \star} \\
(0.003)\end{array}$ & $\begin{array}{l}0.012^{\star \star \star} \\
(0.003)\end{array}$ & $\begin{array}{l}0.012^{* * *} \\
(0.003)\end{array}$ & $\begin{array}{l}0.012^{* * *} \\
(0.003)\end{array}$ & $\begin{array}{l}0.014^{* \star *} \\
(0.003)\end{array}$ & $\begin{array}{l}0.013^{* \star *} \\
(0.003)\end{array}$ & $\begin{array}{l}0.013^{\star \star \star} \\
(0.003)\end{array}$ & $\begin{array}{c}0.013^{\star \star \star} \\
(0.003)\end{array}$ \\
\hline Services & $\begin{array}{l}0.061^{\star \star *} \\
(0.003)\end{array}$ & $\begin{array}{l}0.061^{\star \star *} \\
(0.003)\end{array}$ & $\begin{array}{c}0.060^{* \star *} \\
(0.003)\end{array}$ & $\begin{array}{c}0.060^{* \star *} \\
(0.003)\end{array}$ & $\begin{array}{l}0.062^{* \star *} \\
(0.003)\end{array}$ & $\begin{array}{l}0.061^{* \star *} \\
(0.003)\end{array}$ & $\begin{array}{l}0.061^{\star \star \star} \\
(0.003)\end{array}$ & $\begin{array}{l}0.061^{\star \star \star *} \\
(0.003)\end{array}$ \\
\hline Medium firm (size) & $\begin{array}{l}0.145^{\star \star \star} \\
(0.003)\end{array}$ & $\begin{array}{l}0.142^{\star \star \star} \\
(0.003)\end{array}$ & $\begin{array}{l}0.142^{\star \star \star} \\
(0.003)\end{array}$ & $\begin{array}{l}0.142^{* \star *} \\
(0.003)\end{array}$ & $\begin{array}{l}0.144^{* \star *} \\
(0.003)\end{array}$ & $\begin{array}{l}0.141^{\star \star \star} \\
(0.003)\end{array}$ & $\begin{array}{l}0.141^{\star \star \star} \\
(0.003)\end{array}$ & $\begin{array}{l}0.141^{\star \star \star} \\
(0.003)\end{array}$ \\
\hline Large firm (size) & $\begin{array}{l}0.245^{\star \star *} \\
(0.002)\end{array}$ & $\begin{array}{l}0.240^{\star \star *} \\
(0.003)\end{array}$ & $\begin{array}{l}0.239^{* * *} \\
(0.003)\end{array}$ & $\begin{array}{c}0.239^{* * *} \\
(0.003)\end{array}$ & $\begin{array}{l}0.244^{* \star *} \\
(0.002)\end{array}$ & $\begin{array}{l}0.238^{* \star *} \\
(0.003)\end{array}$ & $\begin{array}{l}0.237^{* \star *} \\
(0.003)\end{array}$ & $\begin{array}{c}0.237^{\star \star \star \star} \\
(0.003)\end{array}$ \\
\hline Center & $\begin{array}{l}0.024^{\star * *} \\
(0.003)\end{array}$ & $\begin{array}{l}0.023^{\star \star *} \\
(0.003)\end{array}$ & $\begin{array}{l}0.023^{* \star *} \\
(0.003)\end{array}$ & $\begin{array}{c}0.022^{* \star *} \\
(0.003)\end{array}$ & $\begin{array}{l}0.024^{* * *} \\
(0.003)\end{array}$ & $\begin{array}{l}0.023^{* \star *} \\
(0.003)\end{array}$ & $\begin{array}{l}0.022^{* * *} \\
(0.003)\end{array}$ & $\begin{array}{l}0.021^{* \star \star *} \\
(0.003)\end{array}$ \\
\hline Lisbon & $\begin{array}{l}0.104^{* *} \\
(0.003)\end{array}$ & $\begin{array}{l}0.102^{* \star *} \\
(0.003)\end{array}$ & $\begin{array}{l}0.102^{* * *} \\
(0.003)\end{array}$ & $\begin{array}{l}0.103^{* \star *} \\
(0.003)\end{array}$ & $\begin{array}{l}0.104^{* * *} \\
(0.003)\end{array}$ & $\begin{array}{l}0.102^{* * *} \\
(0.003)\end{array}$ & $\begin{array}{l}0.102^{* \star *} \\
(0.003)\end{array}$ & $\begin{array}{l}0.103^{\star \star \star *} \\
(0.003)\end{array}$ \\
\hline Alentejo & $\begin{array}{l}0.087^{\star \star *} \\
(0.004)\end{array}$ & $\begin{array}{c}0.085^{* \star *} \\
(0.004)\end{array}$ & $\begin{array}{l}0.085^{\star * *} \\
(0.004)\end{array}$ & $\begin{array}{l}0.085^{* * *} \\
(0.004)\end{array}$ & $\begin{array}{l}0.087^{\star \star *} \\
(0.004)\end{array}$ & $\begin{array}{l}0.085^{\star \star *} \\
(0.004)\end{array}$ & $\begin{array}{l}0.085^{\star \star \star} \\
(0.004)\end{array}$ & $\begin{array}{c}0.084^{* \star \star} \\
(0.004)\end{array}$ \\
\hline Algarve & $\begin{array}{l}0.010^{\star *} \\
(0.004)\end{array}$ & $\begin{array}{l}0.008^{*} \\
(0.004)\end{array}$ & $\begin{array}{c}0.007 \\
(0.004)\end{array}$ & $\begin{array}{c}0.007 \\
(0.004)\end{array}$ & $\begin{array}{l}0.009^{\star *} \\
(0.004)\end{array}$ & $\begin{array}{c}0.007 \\
(0.004)\end{array}$ & $\begin{array}{c}0.006 \\
(0.004)\end{array}$ & $\begin{array}{l}0.006 \\
(0.004)\end{array}$ \\
\hline Upper secondary & $\begin{array}{l}0.095^{\star \star *} \\
(0.003)\end{array}$ & $\begin{array}{l}0.095^{\star \star *} \\
(0.003)\end{array}$ & $\begin{array}{c}0.096^{* * *} \\
(0.003)\end{array}$ & $\begin{array}{c}0.096^{* * *} \\
(0.003)\end{array}$ & $\begin{array}{l}0.093^{* * *} \\
(0.003)\end{array}$ & $\begin{array}{l}0.092^{* * *} \\
(0.003)\end{array}$ & $\begin{array}{l}0.094^{* * *} \\
(0.003)\end{array}$ & $\begin{array}{l}0.094^{* * *} \\
(0.003)\end{array}$ \\
\hline Bachelor or more & $\begin{array}{l}0.546^{\star \star *} \\
(0.011)\end{array}$ & $\begin{array}{l}0.547^{\star \star *} \\
(0.011)\end{array}$ & $\begin{array}{l}0.548^{* \star *} \\
(0.011)\end{array}$ & $\begin{array}{l}0.549^{* * *} \\
(0.011)\end{array}$ & $\begin{array}{l}0.542^{* \star *} \\
(0.011)\end{array}$ & $\begin{array}{l}0.544^{* \star *} \\
(0.011)\end{array}$ & $\begin{array}{l}0.545^{\star \star \star} \\
(0.011)\end{array}$ & $\begin{array}{l}0.546^{\star \star \star} \\
(0.011)\end{array}$ \\
\hline Without term contract & & $\begin{array}{l}-0.008^{\star \star} \\
(0.004)\end{array}$ & $\begin{array}{c}-0.044^{* \star *} \\
(0.014)\end{array}$ & $\begin{array}{c}-0.026 \\
(0.019)\end{array}$ & & $\begin{array}{l}-0.009^{\star \star} \\
(0.004)\end{array}$ & $\begin{array}{c}-0.044^{\star \star *} \\
(0.014)\end{array}$ & $\begin{array}{l}-0.028 \\
(0.019)\end{array}$ \\
\hline Fixed term contract & & $\begin{array}{l}0.006 \\
(0.004)\end{array}$ & $\begin{array}{c}0.016 \\
(0.014)\end{array}$ & $\begin{array}{c}0.006 \\
(0.019)\end{array}$ & & $\begin{array}{l}0.008^{*} \\
(0.004)\end{array}$ & $\begin{array}{c}0.017 \\
(0.014)\end{array}$ & $\begin{array}{c}0.006 \\
(0.019)\end{array}$ \\
\hline Temporary substitute & & $\begin{array}{c}-0.022^{\star \star} \\
(0.009)\end{array}$ & $\begin{array}{c}-0.066 \\
(0.066)\end{array}$ & $\begin{array}{l}-0.118 \\
(0.085)\end{array}$ & & $\begin{array}{l}-0.022^{* \star} \\
(0.009)\end{array}$ & $\begin{array}{l}-0.066 \\
(0.066)\end{array}$ & $\begin{array}{l}-0.118 \\
(0.085)\end{array}$ \\
\hline Without term contract * variance & & & $\begin{array}{l}0.209^{\star *} \\
(0.084)\end{array}$ & $\begin{array}{l}0.172^{*} \\
(0.089)\end{array}$ & & & $\begin{array}{l}0.206^{\star *} \\
(0.084)\end{array}$ & $\begin{array}{l}0.172^{*} \\
(0.089)\end{array}$ \\
\hline Fixed term contract * variance & & & $\begin{array}{l}-0.047 \\
(0.084)\end{array}$ & $\begin{array}{l}-0.026 \\
(0.090)\end{array}$ & & & $\begin{array}{l}-0.048 \\
(0.084)\end{array}$ & $\begin{array}{l}-0.025 \\
(0.090)\end{array}$ \\
\hline Temporary substitute * variance & & & $\begin{array}{c}0.253 \\
(0.392)\end{array}$ & $\begin{array}{c}0.356 \\
(0.425)\end{array}$ & & & $\begin{array}{c}0.254 \\
(0.392)\end{array}$ & $\begin{array}{c}0.358 \\
(0.425)\end{array}$ \\
\hline Without term contract * ${ }^{*}$ skewness & & & & $\begin{array}{l}-0.007^{*} \\
(0.004)\end{array}$ & & & & $\begin{array}{l}-0.006^{*} \\
(0.004)\end{array}$ \\
\hline Fixed term contract * skewness & & & & $\begin{array}{c}0.005 \\
(0.004)\end{array}$ & & & & $\begin{array}{l}0.005 \\
(0.004)\end{array}$ \\
\hline Temporary substitute * skewness & & & & $\begin{array}{l}0.022^{*} \\
(0.011)\end{array}$ & & & & $\begin{array}{l}0.022^{*} \\
(0.011)\end{array}$ \\
\hline Same firm & & & & & $\begin{array}{l}0.013^{* * *} \\
(0.003)\end{array}$ & $\begin{array}{l}0.014^{* * *} \\
(0.003)\end{array}$ & $\begin{array}{l}0.014^{\star \star *} \\
(0.003)\end{array}$ & $\begin{array}{l}0.014^{* * *} \\
(0.003)\end{array}$ \\
\hline SSR UB & & & & & $\begin{array}{l}-0.012^{\star *} \\
(0.005)\end{array}$ & $\begin{array}{c}-0.013^{\star *} \\
(0.005)\end{array}$ & $\begin{array}{c}-0.013^{* \star *} \\
(0.005)\end{array}$ & $\begin{array}{c}-0.013^{* * *} \\
(0.005)\end{array}$ \\
\hline SSR No Benefit & & & & & $\begin{array}{c}-0.022^{* * *} \\
(0.003)\end{array}$ & $\begin{array}{c}-0.022^{* * *} \\
(0.003)\end{array}$ & $\begin{array}{c}-0.022^{* * *} \\
(0.003)\end{array}$ & $\begin{array}{c}-0.022^{* * *} \\
(0.003)\end{array}$ \\
\hline SSR Employed & & & & & $\begin{array}{c}-0.011^{\star \star \star *} \\
(0.004)\end{array}$ & $\begin{array}{c}-0.010^{* \star *} \\
(0.004)\end{array}$ & $\begin{array}{c}-0.011^{\star \star *} \\
(0.004)\end{array}$ & $\begin{array}{c}-0.010^{* * \star} \\
(0.004)\end{array}$ \\
\hline SSR Lost & & & & & $\begin{array}{c}-0.040^{* * *} \\
(0.008)\end{array}$ & $\begin{array}{c}-0.041^{* \star *} \\
(0.008)\end{array}$ & $\begin{array}{c}-0.041^{\text {***}} \\
(0.008)\end{array}$ & $\begin{array}{c}-0.041^{* * *} \\
(0.008)\end{array}$ \\
\hline Constant & $\begin{array}{c}-0.861^{\star \star \star} \\
(0.013)\end{array}$ & $\begin{array}{c}-0.858^{\star \star \star} \\
(0.013)\end{array}$ & $\begin{array}{c}-0.845^{\star \star \star} \\
(0.018)\end{array}$ & $\begin{array}{c}-0.847^{\star \star *} \\
(0.021)\end{array}$ & $\begin{array}{c}-0.852^{\star * *} \\
(0.013)\end{array}$ & $\begin{array}{c}-0.850^{\star \star *} \\
(0.013)\end{array}$ & $\begin{array}{c}-0.837^{\star \star *} \\
(0.018)\end{array}$ & $\begin{array}{c}-0.837^{\star * *} \\
(0.021)\end{array}$ \\
\hline $\begin{array}{l}\text { Observations } \\
\text { R-squared }\end{array}$ & $\begin{array}{c}89,899 \\
0.322\end{array}$ & $\begin{array}{c}89,899 \\
0.322\end{array}$ & $\begin{array}{c}89,899 \\
0.322\end{array}$ & $\begin{array}{c}89,899 \\
0.323\end{array}$ & $\begin{array}{c}89,899 \\
0.323\end{array}$ & $\begin{array}{c}89,899 \\
0.323\end{array}$ & $\begin{array}{c}89,899 \\
0.324\end{array}$ & $\begin{array}{c}89,899 \\
0.324\end{array}$ \\
\hline
\end{tabular}

${ }^{\star \star * \star} p<0.01,{ }^{* \star} p<0.05,{ }^{\star} p<0.1$ 
Table 8. Dependent variable: log wage 2006 - log wage 2000

\begin{tabular}{|c|c|c|c|c|c|c|c|c|}
\hline & (1) & (2) & (3) & (4) & (5) & (6) & (7) & (8) \\
\hline Variance & & & $\begin{array}{c}0.569^{* * *} \\
-0.088\end{array}$ & $\begin{array}{c}0.477^{* * *} \\
-0.076\end{array}$ & $\begin{array}{c}0.529^{* * *} \\
-0.074\end{array}$ & $\begin{array}{c}0.626^{* * *} \\
-0.077\end{array}$ & $\begin{array}{c}0.523^{* * *} \\
-0.077\end{array}$ & $\begin{array}{c}0.523^{* * *} \\
-0.077\end{array}$ \\
\hline Skewness & & & $\begin{array}{c}-0.020^{* * *} \\
-0.004\end{array}$ & $\begin{array}{c}-0.012^{* * *} \\
-0.004\end{array}$ & $\begin{array}{c}-0.016^{* * *} \\
-0.004\end{array}$ & $\begin{array}{c}-0.018^{* * *} \\
-0.005\end{array}$ & $\begin{array}{c}-0.015^{* * *} \\
-0.004\end{array}$ & $\begin{array}{c}-0.015^{* * *} \\
-0.004\end{array}$ \\
\hline Male & $\begin{array}{l}0.063^{* * *} \\
(0.008)\end{array}$ & $\begin{array}{c}0.062^{* * *} \\
(0.006)\end{array}$ & $\begin{array}{c}0.060^{* * *} \\
(0.006)\end{array}$ & $\begin{array}{c}0.058^{* * *} \\
(0.007)\end{array}$ & $\begin{array}{l}0.061^{* * *} \\
(0.006)\end{array}$ & $\begin{array}{c}0.061^{* * *} \\
(0.006)\end{array}$ & $\begin{array}{c}0.062^{* * *} \\
(0.006)\end{array}$ & $\begin{array}{c}0.062^{* * *} \\
(0.006)\end{array}$ \\
\hline Age & $\begin{array}{c}-0.008^{* * *} \\
(0.001)\end{array}$ & $\begin{array}{c}-0.009^{* * *} \\
(0.001)\end{array}$ & $\begin{array}{c}-0.010^{* * *} \\
(0.001)\end{array}$ & $\begin{array}{c}-0.010^{* * *} \\
(0.001)\end{array}$ & $\begin{array}{c}-0.010^{* * *} \\
(0.001)\end{array}$ & $\begin{array}{c}-0.010^{* * *} \\
(0.001)\end{array}$ & $\begin{array}{c}-0.011^{* * *} \\
(0.001)\end{array}$ & $\begin{array}{c}-0.011^{* * *} \\
(0.001)\end{array}$ \\
\hline Age square & $\begin{array}{l}0.000^{* * *} \\
(0.000)\end{array}$ & $\begin{array}{l}0.000^{* * *} \\
(0.000)\end{array}$ & $\begin{array}{c}0.000^{* * *} \\
(0.000)\end{array}$ & $\begin{array}{c}0.000^{* * *} \\
(0.000)\end{array}$ & $\begin{array}{l}0.000^{* * *} \\
(0.000)\end{array}$ & $\begin{array}{c}0.000^{* * *} \\
(0.000)\end{array}$ & $\begin{array}{l}0.000^{* * *} \\
(0.000)\end{array}$ & $\begin{array}{l}0.000^{* * *} \\
(0.000)\end{array}$ \\
\hline Construction & & $\begin{array}{l}0.039^{* * *} \\
(0.012)\end{array}$ & & $\begin{array}{l}0.038^{* * *} \\
(0.011)\end{array}$ & $\begin{array}{c}0.012 \\
(0.010)\end{array}$ & $\begin{array}{c}0.007 \\
(0.010)\end{array}$ & $\begin{array}{c}0.009 \\
(0.010)\end{array}$ & $\begin{array}{c}0.009 \\
(0.010)\end{array}$ \\
\hline Commerce, Tourism, & & & & & & & & \\
\hline Transportation & & $\begin{array}{c}0.047^{* * *} \\
(0.009)\end{array}$ & & $\begin{array}{l}0.043^{* * *} \\
(0.008)\end{array}$ & $\begin{array}{c}0.028^{* * *} \\
(0.007)\end{array}$ & $\begin{array}{c}0.024^{* * *} \\
(0.006)\end{array}$ & $\begin{array}{c}0.032^{* * *} \\
(0.007)\end{array}$ & $\begin{array}{c}0.032^{* * *} \\
(0.007)\end{array}$ \\
\hline Services & & $\begin{array}{l}0.026^{* *} \\
(0.011)\end{array}$ & & $\begin{array}{c}0.012 \\
(0.012)\end{array}$ & $\begin{array}{c}0.007 \\
(0.009)\end{array}$ & $\begin{array}{c}0.005 \\
(0.008)\end{array}$ & $\begin{array}{c}0.007 \\
(0.008)\end{array}$ & $\begin{array}{c}0.007 \\
(0.008)\end{array}$ \\
\hline Medium firm (size) & & $\begin{array}{c}-0.043^{* * *} \\
(0.006)\end{array}$ & & & $\begin{array}{c}-0.043^{* * *} \\
(0.006)\end{array}$ & $\begin{array}{c}-0.043^{* * *} \\
(0.006)\end{array}$ & $\begin{array}{c}-0.043^{* * *} \\
(0.006)\end{array}$ & $\begin{array}{c}-0.043^{* * *} \\
(0.006)\end{array}$ \\
\hline Large firm (size) & & $\begin{array}{c}-0.090^{\star \star *} \\
(0.009)\end{array}$ & & & $\begin{array}{c}-0.090^{* * *} \\
(0.009)\end{array}$ & $\begin{array}{c}-0.089^{* * *} \\
(0.009)\end{array}$ & $\begin{array}{c}-0.086^{* * *} \\
(0.009)\end{array}$ & $\begin{array}{c}-0.086^{\star * *} \\
(0.009)\end{array}$ \\
\hline Center & & $\begin{array}{c}0.006 \\
(0.008)\end{array}$ & & & & $\begin{array}{l}-0.007 \\
(0.006)\end{array}$ & $\begin{array}{l}-0.002 \\
(0.007)\end{array}$ & $\begin{array}{l}-0.002 \\
(0.007)\end{array}$ \\
\hline Lisbon & & $\begin{array}{l}0.020^{* *} \\
(0.009)\end{array}$ & & & & $\begin{array}{l}-0.011^{*} \\
(0.007)\end{array}$ & $\begin{array}{l}-0.006 \\
(0.008)\end{array}$ & $\begin{array}{l}-0.006 \\
(0.008)\end{array}$ \\
\hline Alentejo & & $\begin{array}{c}0.002 \\
(0.010)\end{array}$ & & & & $\begin{array}{c}-0.013^{* *} \\
(0.006)\end{array}$ & $\begin{array}{l}-0.007 \\
(0.008)\end{array}$ & $\begin{array}{c}-0.007 \\
(0.008)\end{array}$ \\
\hline Algarve & & $\begin{array}{l}0.029^{\star *} \\
(0.013)\end{array}$ & & & & $\begin{array}{c}0.036^{\star * *} \\
(0.010)\end{array}$ & $\begin{array}{l}0.036^{\star \star *} \\
(0.009)\end{array}$ & $\begin{array}{c}0.036^{\star * *} \\
(0.009)\end{array}$ \\
\hline Upper Secondary & & & & & & & $\begin{array}{c}0.062^{\star \star *} \\
(0.007)\end{array}$ & $\begin{array}{c}0.062^{* \star *} \\
(0.007)\end{array}$ \\
\hline Bachelor or more & & & & & & & $\begin{array}{l}0.187^{* * *} \\
(0.035)\end{array}$ & $\begin{array}{l}0.187^{* * *} \\
(0.035)\end{array}$ \\
\hline Same firm & $\begin{array}{l}0.015^{\star * *} \\
(0.002)\end{array}$ & $\begin{array}{c}0.016^{* * *} \\
(0.001)\end{array}$ & $\begin{array}{c}0.009^{* * *} \\
(0.002)\end{array}$ & $\begin{array}{c}0.010^{* * *} \\
(0.001)\end{array}$ & $\begin{array}{c}0.011^{* * *} \\
(0.001)\end{array}$ & $\begin{array}{c}0.011^{* * *} \\
(0.001)\end{array}$ & & \\
\hline Years of Education & & & & & & & & $\begin{array}{c}-0.004 \\
(0.007)\end{array}$ \\
\hline Constant & $\begin{array}{c}0.226^{* * *} \\
(0.031)\end{array}$ & $\begin{array}{c}0.242^{* * *} \\
(0.024)\end{array}$ & $\begin{array}{c}0.256^{* * *} \\
(0.030)\end{array}$ & $\begin{array}{l}0.223^{* * *} \\
(0.029)\end{array}$ & $\begin{array}{c}0.258^{* * *} \\
(0.026)\end{array}$ & $\begin{array}{c}0.252^{* * *} \\
(0.026)\end{array}$ & $\begin{array}{c}0.352^{* * *} \\
(0.026)\end{array}$ & $\begin{array}{c}0.352^{* * *} \\
(0.026)\end{array}$ \\
\hline $\begin{array}{l}\text { Observations } \\
\text { R-squared }\end{array}$ & $\begin{array}{c}58,897 \\
0.015\end{array}$ & $\begin{array}{l}58,897 \\
0.027\end{array}$ & $\begin{array}{l}58,897 \\
0.020\end{array}$ & $\begin{array}{l}58,897 \\
0.021\end{array}$ & $\begin{array}{l}58,897 \\
0.029\end{array}$ & $\begin{array}{l}58,897 \\
0.030\end{array}$ & $\begin{array}{l}58,897 \\
0.030\end{array}$ & $\begin{array}{l}58,897 \\
0.030\end{array}$ \\
\hline
\end{tabular}

*** $p<0.01,{ }^{* *} p<0.05,{ }^{*} p<0.1$ 
Figure 1 - Group mean variance, by year

1.a) first job in 2000 and follow up to 2013

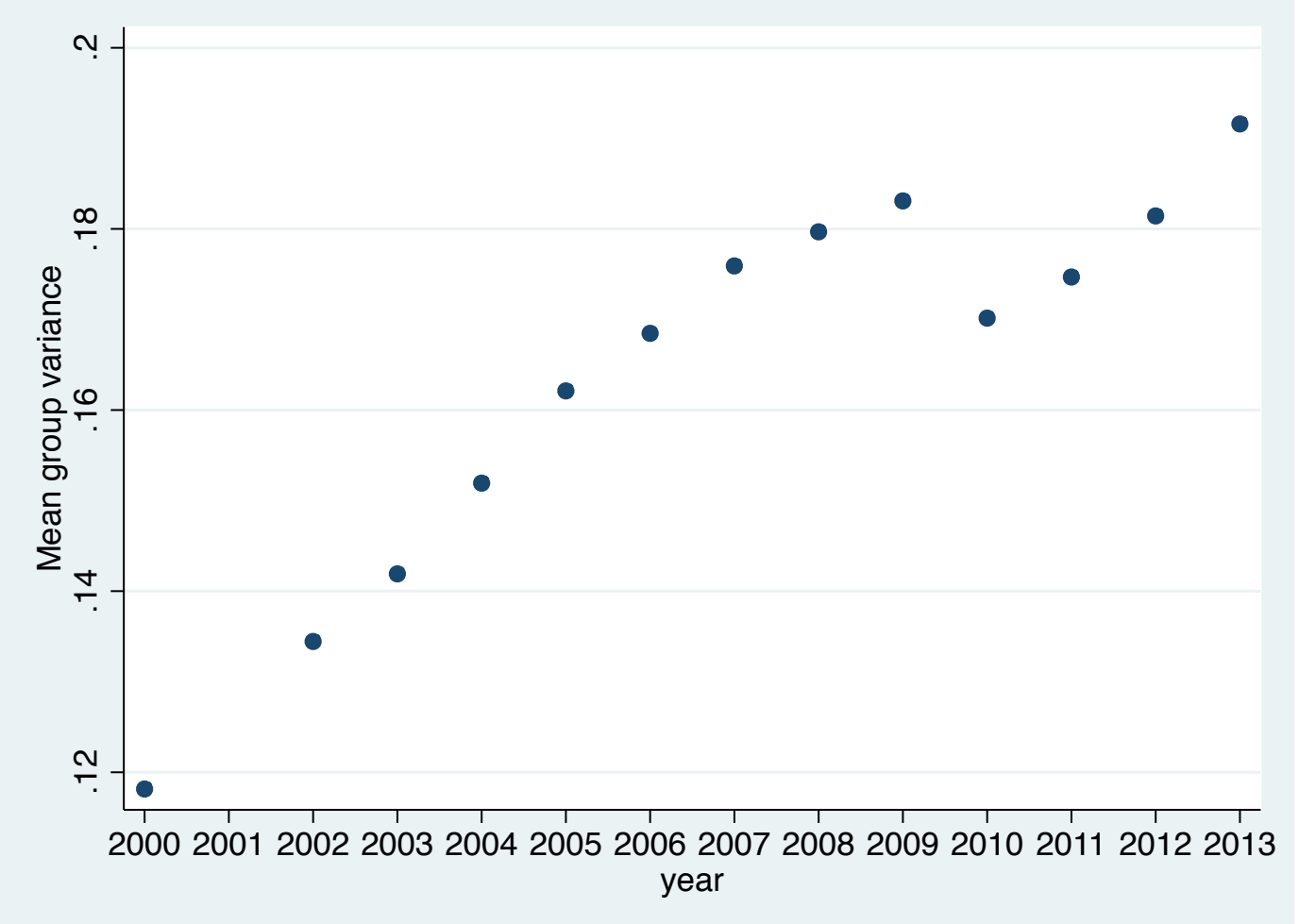

1.b) first job in 1994 and follow up to 2013

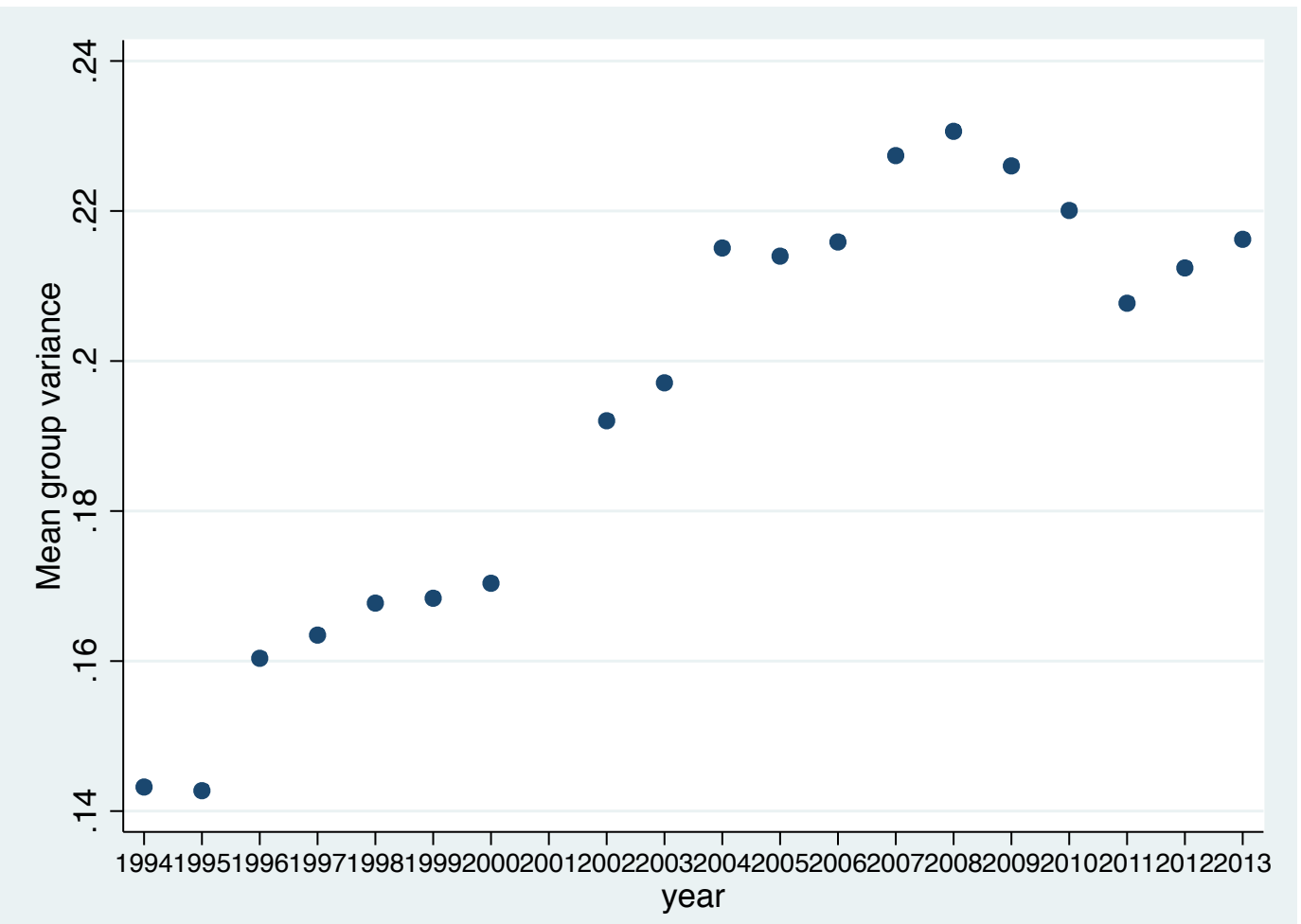


APPENDIX A - Data

Table A1 - Definitions

The table lists all variables used to predict the log of the hourly wage.

\begin{tabular}{ll}
\hline Variable & Description \\
\hline Base wage & $\begin{array}{l}\text { Labor earnings that are fixed and paid regularly on a } \\
\text { monthly base. } \\
\text { The sum of base wage, regular payments (e.g., seniority and } \\
\text { transportation), irregular benefits (profits and premium), } \\
\text { and overtime hours payments. }\end{array}$ \\
Total earnings & $\begin{array}{l}\text { Actual hours during a normal week at the going wage. } \\
\text { Normal hours }\end{array}$ \\
Time worked in a week at an overtime premium (50\% \\
for the first hour, 75\% for additional hours). \\
Sum of normal and overtime hours. \\
Rotal hours
\end{tabular}




\section{Table A2 - Descriptive statistics}

This table reports summary statistics (mean, standard deviation, minimum and maximum) for the year 2000. Variables represented are those described in detail in Table A1. The units are explained in front of the variables, while gender, industry, labour market state in 2006, education, firm size and region are shown as percentage.

\begin{tabular}{|c|c|c|c|c|}
\hline & Mean & $\begin{array}{l}\text { Standard } \\
\text { Deviation }\end{array}$ & Min & Max \\
\hline Variance 2006 & 0.18 & 0.05 & 0.05 & 0.48 \\
\hline Skewness 2006 & 1.53 & 0.90 & -0.79 & 4.15 \\
\hline Total real wage (2008 euros) & 607.26 & 104.63 & 210.46 & 26570.90 \\
\hline Total real hourly wage (2008 euros) & 3.55 & 0.62 & 1.65 & 164.02 \\
\hline Total real hourly wage (log) & 0.02 & 0.35 & -0.67 & 3.93 \\
\hline Total monthly hours & 171.19 & 11.30 & 74.00 & 346.00 \\
\hline Male & 0.56 & 0.50 & & \\
\hline Age & 21.93 & 9.64 & 14.33 & 2000.83 \\
\hline Years of Education & 8.38 & 2.98 & 4.00 & 16.00 \\
\hline \multicolumn{5}{|l|}{ Education(5 categories): } \\
\hline Basic School & 0.12 & 0.33 & & \\
\hline Preparatory & 0.27 & 0.45 & & \\
\hline Lower secondary & 0.30 & 0.46 & & \\
\hline Upper secondary & 0.27 & 0.44 & & \\
\hline Bachelor & 0.02 & 0.13 & & \\
\hline College & 0.02 & 0.15 & & \\
\hline \multicolumn{5}{|l|}{ Industry (4 categories): } \\
\hline Manufacturing & 0.29 & 0.45 & & \\
\hline Construction & 0.13 & 0.33 & & \\
\hline Commerce, Tourism, Transportation & 0.40 & 0.49 & & \\
\hline Services & 0.19 & 0.39 & & \\
\hline Employed in 2006: Changed firm & 0.45 & 0.50 & & \\
\hline Employed in 2006: Same firm & 0.22 & 0.41 & & \\
\hline Social security records: Unemployment benefit & 0.04 & 0.19 & & \\
\hline Social security records: Not receiving Unemployment benefits & 0.22 & 0.41 & & \\
\hline Social security records: Employed & 0.07 & 0.25 & & \\
\hline Social security records: status unkown & 0.01 & 0.11 & & \\
\hline \multicolumn{5}{|l|}{ Firm size ( 3 categories): } \\
\hline Small firm (-18 workers) & 0.42 & 0.49 & & \\
\hline Medium firm (19-89 workers) & 0.25 & 0.43 & & \\
\hline Large firm (90+ workers) & 0.33 & 0.47 & & \\
\hline \multicolumn{5}{|l|}{ Region (5 categories): } \\
\hline North & 0.33 & 0.47 & & \\
\hline Center & 0.13 & 0.34 & & \\
\hline Lisbon & 0.41 & 0.49 & & \\
\hline Alentejo & 0.08 & 0.26 & & \\
\hline Algarve & 0.06 & 0.24 & & \\
\hline
\end{tabular}


Table A3 - Correlation matrix

\begin{tabular}{|c|c|c|c|c|c|c|c|c|c|c|c|c|}
\hline & $\begin{array}{l}\text { Variance } \\
2006\end{array}$ & $\begin{array}{c}\text { Skewness } \\
2006\end{array}$ & $\begin{array}{c}\text { Total real } \\
\text { wage (2008 } \\
\text { euros) }\end{array}$ & $\begin{array}{c}\text { Total real } \\
\text { hourly wage } \\
\text { (2008 } \\
\text { euros) }\end{array}$ & $\begin{array}{l}\text { Total real } \\
\text { hourly wage } \\
\text { (log) }\end{array}$ & $\begin{array}{c}\text { Total } \\
\text { monthly } \\
\text { hours }\end{array}$ & Male & Age & Manufacturing & Construction & $\begin{array}{c}\text { Commerce, } \\
\text { Tourism, } \\
\text { Transportation }\end{array}$ & Services \\
\hline Variance 2006 & 1 & & & & & & & & & & & \\
\hline Skewness 2006 & $-0.292^{* * *}$ & 1 & & & & & & & & & & \\
\hline Total real wage (2008 euros) & $0.199 * * *$ & $-0.164^{* * *}$ & 1 & & & & & & & & & \\
\hline Total real hourly wage (2008 euros) & $0.169^{* * *}$ & $-0.138^{* * *}$ & $0.828^{* * *}$ & 1 & & & & & & & & \\
\hline Total real hourly wage $(\log )$ & $0.248^{* * *}$ & $-0.227^{* * *}$ & $0.841^{* * *}$ & $0.759 * * *$ & 1 & & & & & & & \\
\hline Total monthly hours & $-0.0118^{* * *}$ & $0.00790^{*}$ & $0.169^{* * *}$ & $-0.0810^{* * *}$ & $-0.0169 * * *$ & 1 & & & & & & \\
\hline Male & $-0.0399 * * *$ & $-0.0294^{* * *}$ & $0.144^{* * *}$ & $0.111^{* * *}$ & $0.180^{* * *}$ & $0.0427^{* * *}$ & 1 & & & & & \\
\hline Age & $0.0214^{* * *}$ & $-0.0162^{* * *}$ & $0.0154^{* * *}$ & $0.0216^{* * *}$ & $0.0348^{* * *}$ & $-0.0526^{* * *}$ & 0.000881 & 1 & & & & \\
\hline Manufacturing & $-0.375^{* * *}$ & $0.427^{* * *}$ & $-0.0781^{* * *}$ & $-0.0709 * * *$ & $-0.103^{* * *}$ & $0.0281 * * *$ & $-0.0166^{* * *}$ & $-0.0143^{* * *}$ & 1 & & & \\
\hline Construction & $-0.0220^{* * *}$ & $-0.152^{* * *}$ & $-0.0284^{* * *}$ & $-0.0252^{* * *}$ & $-0.0321^{* * *}$ & $-0.00904^{* *}$ & $0.290^{* * *}$ & -0.00176 & $-0.239 * * *$ & 1 & & \\
\hline Commerce, Tourism, Transportation & $0.164^{* * *}$ & $-0.216^{* * *}$ & $-0.0122^{* * *}$ & $-0.0129^{* * *}$ & $-0.0202 * * *$ & $0.0256 * * *$ & $-0.0829^{* * *}$ & 0.00323 & $-0.515^{* * *}$ & $-0.312^{* * * *}$ & 1 & \\
\hline Services & $0.245^{* * *}$ & $-0.0918 * * *$ & $0.130^{* * *}$ & $0.119^{* * *}$ & $0.172^{* * *}$ & $-0.0567 * * *$ & $-0.124 * * *$ & $0.0139 * * *$ & $-0.303^{* * *}$ & $-0.183^{* * *}$ & $-0.395 * * *$ & 1 \\
\hline Employed in 2006: Changed firm & 0.00193 & $0.0105^{* *}$ & $0.0395 * * *$ & $0.0279 * * *$ & $0.0491^{* * *}$ & $0.0355 * * *$ & $-0.0129 * * *$ & 0.00616 & $0.0555 * * *$ & $-0.0594^{* * *}$ & -0.00463 & $-0.00759 *$ \\
\hline Employed in 2006: Same firm & -0.00616 & $0.0200^{* * *}$ & $-0.0183^{* * *}$ & $-0.0159 * * *$ & $-0.0215^{* * *}$ & -0.00222 & $-0.0642^{* * *}$ & 0.00518 & $0.0124^{* * *}$ & $-0.0231^{* * *}$ & $0.00644^{*}$ & -0.00272 \\
\hline Unemployed in 2006 & $-0.0492^{* * *}$ & $0.0380^{* * *}$ & $-0.0440 * * *$ & $-0.0360^{* * *}$ & $-0.0612^{* * *}$ & $-0.0155^{* * *}$ & $0.0312^{* * *}$ & $-0.00715^{*}$ & 0.00210 & $0.0731 * * *$ & $-0.0286 * * *$ & $-0.0287^{* * *}$ \\
\hline Non participating labor market in 2006 & $0.0143^{* * *}$ & $-0.0145^{* * *}$ & $-0.0107^{* *}$ & $-0.00673^{*}$ & $-0.0144^{* * *}$ & $-0.00912^{* *}$ & $-0.0137^{* * *}$ & -0.00204 & $-0.0139^{* * *}$ & -0.00359 & 0.00590 & $0.0117^{* * *}$ \\
\hline Small firm (-18 workers) & $-0.0424^{* * *}$ & $0.0147^{* * *}$ & $-0.229 * * *$ & $-0.184^{* * *}$ & $-0.314^{* * *}$ & $-0.0540^{* * *}$ & $0.0241^{* * *}$ & -0.00361 & $-0.138^{* * *}$ & $0.137^{* * *}$ & $0.101^{* * *}$ & $-0.0837^{* * *}$ \\
\hline Medium firm (19-89 workers) & $-0.0470^{* * *}$ & $0.0522^{* * *}$ & $0.0209 * * *$ & $0.0204^{* * *}$ & $0.0237^{* * *}$ & $-0.0289 * * *$ & $0.00672^{*}$ & -0.00290 & $0.0977^{* * *}$ & -0.00340 & $-0.0408^{* * *}$ & $-0.0585^{* * *}$ \\
\hline Large firm (90+ workers) & $0.0873^{* * *}$ & $-0.0632^{* * *}$ & $0.220^{* * *}$ & $0.174^{* * *}$ & $0.306^{* * *}$ & $0.0829 * * *$ & $-0.0313^{* * *}$ & $0.00643^{*}$ & $0.0548^{* * *}$ & $-0.140^{* * *}$ & $-0.0678^{* * *}$ & $0.141^{* * *}$ \\
\hline Years of Education & $0.466^{* * *}$ & $-0.399 * * *$ & $0.206^{* * *}$ & $0.178^{* * *}$ & $0.272^{* * *}$ & $-0.0221^{* * *}$ & $-0.137^{* * *}$ & $0.0135^{* * *}$ & $-0.166^{* * *}$ & $-0.195^{* * *}$ & $0.117^{* * *}$ & $0.210^{* * *}$ \\
\hline Lower secondary or less & $-0.535 * * *$ & $0.408^{* * *}$ & $-0.182 * * *$ & $-0.158^{* * *}$ & $-0.246^{* * *}$ & $0.0370^{* * *}$ & $0.136^{* * *}$ & $-0.0193 * * *$ & $0.146^{* * *}$ & $0.147^{* * *}$ & $-0.0694 * * *$ & $-0.207 * * *$ \\
\hline Upper secondary & $0.487^{* * *}$ & $-0.359^{* * *}$ & $0.121^{* * *}$ & $0.105^{* * *}$ & $0.178^{* * *}$ & $-0.0254^{* * *}$ & $-0.127^{* * *}$ & $0.0154^{* * *}$ & $-0.128^{* * *}$ & $-0.136^{* * *}$ & $0.0781^{* * *}$ & $0.165^{* * *}$ \\
\hline Bachelo & $0.200^{* * *}$ & $-0.195 * * *$ & $0.221^{* * *}$ & $0.194 * * *$ & $0.249 * * *$ & $-0.0425^{* * *}$ & $-0.0413^{* * *}$ & $0.0147^{* * *}$ & $-0.0726 * * *$ & $-0.0496 * * *$ & $-0.0256 * * *$ & $0.158^{* * *}$ \\
\hline North & $-0.294^{* * *}$ & $0.459^{* * *}$ & $-0.154^{* * *}$ & $-0.124^{* * *}$ & $-0.208^{* * *}$ & $-0.0315^{* * *}$ & $0.00829 *$ & $-0.0140^{* * *}$ & $0.244^{* * *}$ & $0.0587 * * *$ & $-0.140^{* * *}$ & $-0.155^{* * *}$ \\
\hline Center & $-0.0315^{* * *}$ & $0.112^{* * *}$ & $-0.0540^{* * *}$ & $-0.0439^{* * *}$ & $-0.0784^{* * *}$ & -0.00370 & $0.0187^{* * *}$ & -0.00267 & $0.118^{* * *}$ & $0.0257 * * *$ & $-0.0586^{* * *}$ & $-0.0843^{* * *}$ \\
\hline Lisbon & $0.409^{* * *}$ & $-0.455^{* * *}$ & $0.214^{* * *}$ & $0.174^{* * *}$ & $0.291^{* * *}$ & $0.0238^{* * *}$ & $-0.0178^{* * *}$ & $0.0205^{* * *}$ & $-0.238^{* * *}$ & $-0.0934^{* * *}$ & $0.0988^{* * *}$ & $0.230^{* * *}$ \\
\hline Alentejo & $-0.0259^{* * *}$ & $-0.0719^{* * *}$ & $-0.0191 * * *$ & $-0.0137^{* * *}$ & $-0.0182^{* * *}$ & -0.000160 & 0.00231 & -0.00269 & $-0.0686^{* * *}$ & $0.0232 * * *$ & $0.0645^{* * *}$ & $-0.0216 * * *$ \\
\hline Algarve & $-0.199 * * *$ & $-0.0423 * * *$ & $-0.0436 * * *$ & $-0.0387 * *$ & $-0.0639 * * *$ & $0.0184^{* * *}$ & $-0.00868^{* *}$ & $-0.00821^{*}$ & $-0.0793 * * *$ & $0.0159^{* * *}$ & $0.0836^{* * *}$ & 0.02 \\
\hline
\end{tabular}

Variance 2006

Skewness 2006
Total real wage (2008 euros)

total real hourly wage (2008 euros)

rotal real hourly wage (log)

Male
Age

Manufacturing

Construction
Commerce, Tourism, Transportation
Services

Employed in 2006: Changed firm

Employed in 2006: Same firm

Unemployed in 2006

Non participating labor market in 2006

Small firm (-18 workers)

Medium frim (19-89 work

Years of Education

Lower secondary or less

Upper secondary

Bachelor or more

North

Center

Lisbon

Algarve

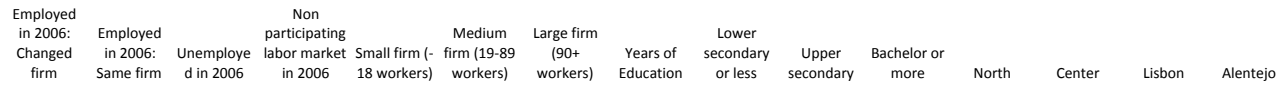

$-0.105 * * * \quad 1$

$0.142^{* * *}-0.0502 * * * \quad 1$

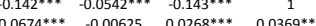

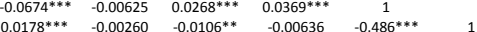

$\begin{array}{llllll}0.0540 * * * & 0.00890 * * & -0.0183 * * * & -0.0327 * * * & -0.599 * * * & -0.409 * * *\end{array}$

$\begin{array}{llllllll}0.0636 * * * & -0.00809 * & -0.0967 * * * & 0.0112 * * * & -0.116^{* * *} & -0.0159 * * * & 0.136 * * * & 1\end{array}$

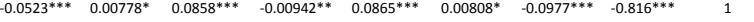

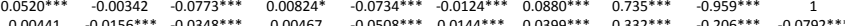

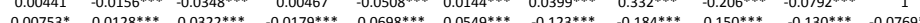

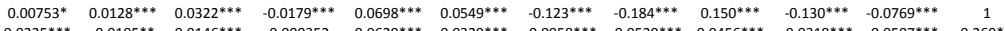

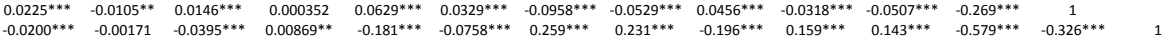

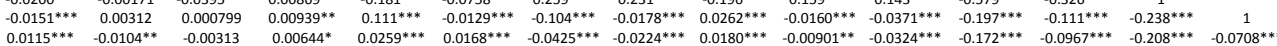


Figure A1 - Mean hourly wage and variance in 2006, by group category

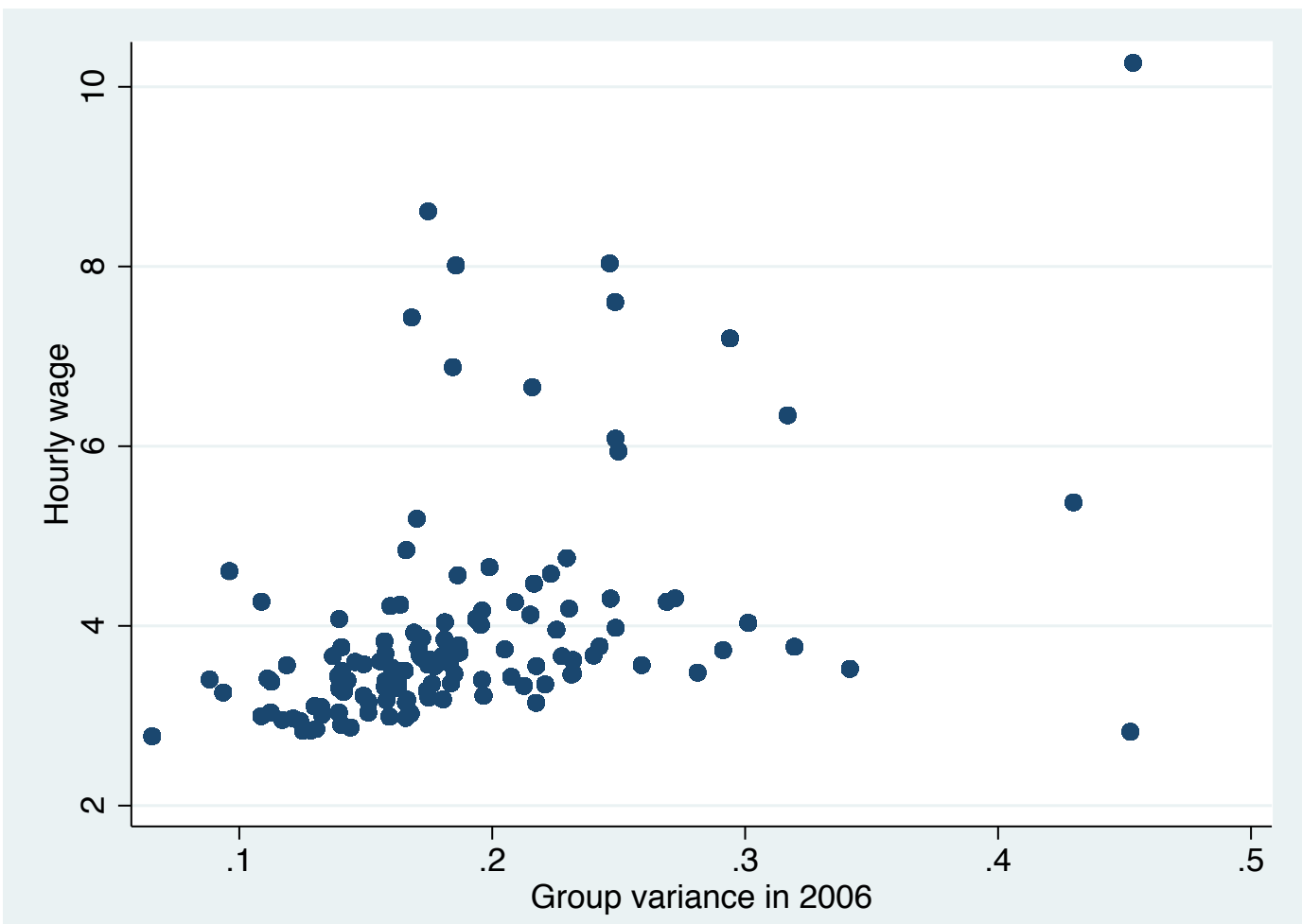

Figure A2 - Mean hourly wage and skewness in 2006, by group category

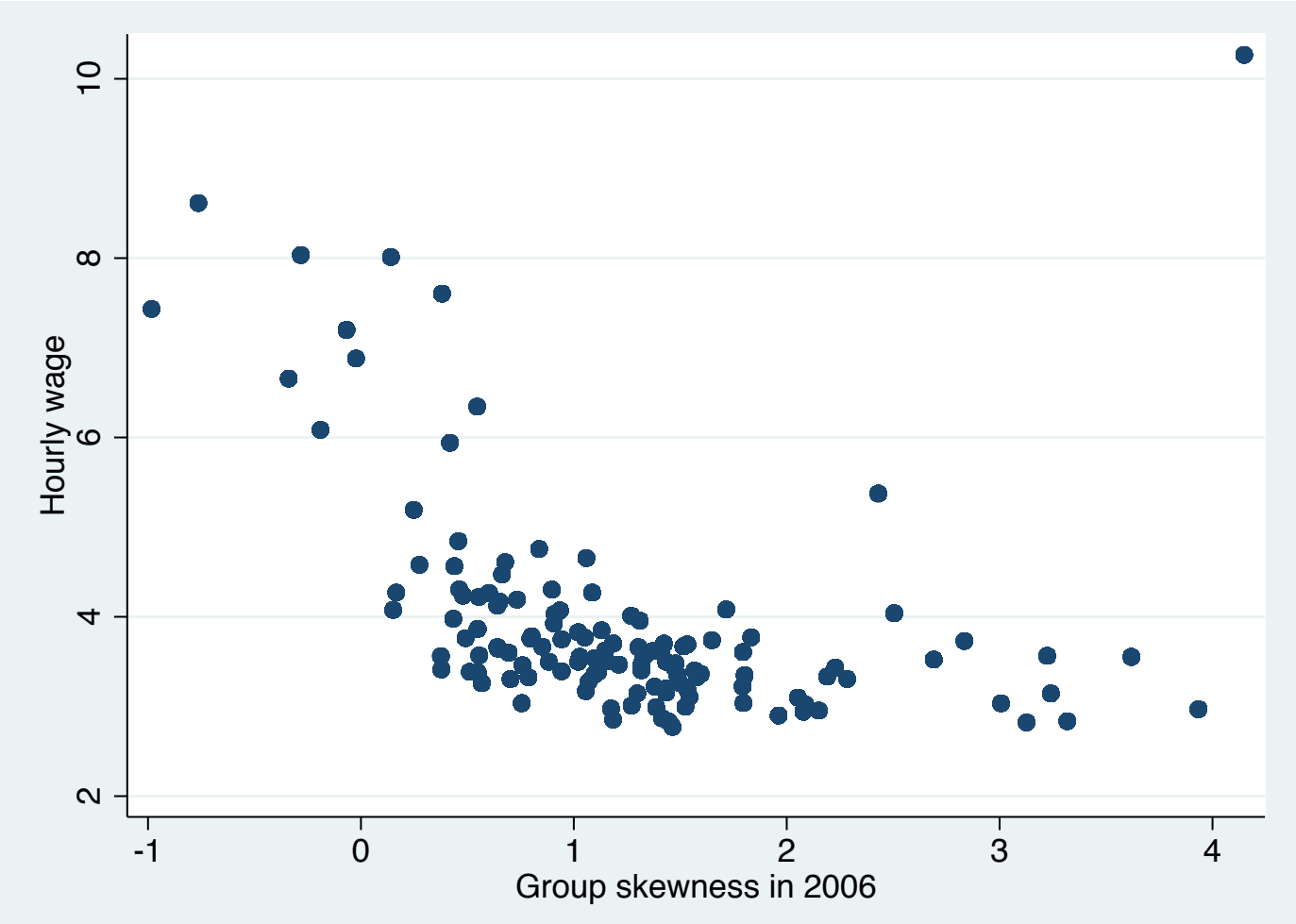




\section{Appendix B. Reflection problem estimator with variance}

As an alternative to solve equation (1), we propose to estimate a model with both a worker fixed effect and group variance. The nonlinear least squares problem is then

$$
\min _{\alpha, \beta, \theta} \sum_{i} \sum_{t}\left[y_{i g t}-\alpha \sigma_{y_{g t i}}^{2}-\beta X_{i t}-\theta_{i}\right]^{2}
$$

where $\mathrm{X}$ includes age, age square tenure, tenure square and log of the firm size, year dummies, $\theta_{i}$ is an individual fixed effect and group $g$ is defined as in the rest of our paper. Equation (2) is written under a "proportionality" assumption made in Arcidiacono et al (2012) and Altonji et al (2015). This assumption states that the relevant importance of the components of $\theta_{i}$ is the same in both the direct effect on $y_{i g t}$ and in the indirect effect through peers. Any two characteristics absorbed in $\theta_{i}$ that have a given direct impact on $y_{i g t}$ , will have exactly the same effect when operating through peers. This assumption implies that after controlling for all of the other covariates, including the worker observed and unobserved fixed ability, the remaining changes in the peer group, are assumed to be orthogonal to the error term $\varepsilon_{i g t}$. Basically, after removing any individual worker effect from the peer group outcome then we have cleared the group outcome from any possible individual reflection.

In order to estimate (2) we can not do it in one step because with a large dataset this is not computationaly feasible. Therefore, we estimate $\alpha$ and $\theta_{i}$ iteratively following the approach used by Guimarães and Portugal (2010). In matrix format, the stacked system has the following form: $Y=\theta F_{1}+\alpha F_{2}+\beta X+\varepsilon$. In this equation $F_{1}$, and $F_{2}$ are high-dimensional matrices for the worker fixed effect, and leave-out variance for group $g$, respectively. $X$ is a matrix of the explanatory variables and calendar year fixed effects from equation (2).

The least squares estimators of $\theta, \alpha$, and $\beta$ solve the following equations:

$$
\left[\begin{array}{ccc}
X^{\prime} X & X^{\prime} F_{1} & X^{\prime} F_{2} \\
F_{1}^{\prime} X & F_{1}^{\prime} F_{1} & F_{1}^{\prime} F_{2} \\
F_{2}^{\prime} X & F_{2}^{\prime} F_{1} & F_{2}^{\prime} F_{2}
\end{array}\right]\left[\begin{array}{c}
\beta \\
\theta \\
\alpha
\end{array}\right]=\left[\begin{array}{c}
X^{\prime} Y \\
F_{1}^{\prime} Y \\
F_{2}^{\prime} Y
\end{array}\right]
$$

It is computationally difficult to invert the left matrix due to the large number of workers, and variances. In this respect, we use an iterative solution that alternates between estimation of $\theta, \alpha$, and $\beta$. 


$$
\left[\begin{array}{l}
\beta \\
\theta \\
\alpha
\end{array}\right]=\left[\begin{array}{c}
\left(X^{\prime} X\right)^{-1} X^{\prime}\left(Y-\theta F_{1}-\alpha F_{2}\right) \\
\left(F_{1}^{\prime} F_{1}\right)^{-1} F_{1}^{\prime}\left(Y-\alpha F_{2}-\beta X\right) \\
\left(F_{2}^{\prime} F_{2}\right)^{-1} F_{2}^{\prime}\left(Y-\theta F_{1}-\beta X\right)
\end{array}\right]
$$

In short, from the previous equations it is clear that at each iteration the effects are simply computed as averages of the residuals.

The iterative solution alternates between estimation of $\theta, \alpha$, and $\beta$ and proceeds as follows. First, the algorithm uses the Frish-Waugh-Lovell theorem to remove the influence of the worker fixed effect from each individual variable. Through the recursive algorithm the current value of $\beta$ can be used to estimate the current value of $\theta$. In estimating $\alpha$ the previous values of $\beta$ and $\theta$ are used. Next, the algorithm restarts and will converge because the parameter updates are chosen according to the equations in (3). Finally, we estimate the regression using the transformed variables with a correction to the degrees of freedom. This approach yields the exact least squares solution for the coefficients and standard errors. 


\section{References}

Angrist, J. (2014), The perils of peer effects, Labour Economics, 30 (1), 98-108

Altonji, J., Huang, C. and Taber, C. (2015), Estimating the Cream Skimming Effect of School Choice. Journal of Political Economy, 123(2), 266 - 324.

Arcidiacono, P., Foster, G., Goodpaster, N. and Kinsler, J. (2012), Estimating spillovers using panel data, with an application to the classroom. Quantitative Economics, 3, 421-470.

Baker, G., M. Gibbs and B. Holmstrom (1994), The wage policy of a firm, Quarterly Journal of Economics, 109 (4), 921-955

Battisti, M. (2013), High Wage Workers and High Wage Peers, Ifo Working Paper Series Ifo Working Paper No. 168, Ifo Institute for Economic Research at the University of Munich.

Berkhout, P., J. Hartog and H. van Ophem (2014), Starting wages respond to employer's risk, Scottish Journal of Political Economy, 61 (3), 229-260

Brock, W. and Durlauf, S. (2000), Interactions-Based Models, in J. Heckman and E. Leamer (eds.), Handbook of Econometrics, vol. 5 (Amsterdam: North-Holland).

Brock, W. and Durlauf, S. (2001), Discrete choice with social interactions. Review of Economic Studies, 68 (2), 235-260.

Cardoso,A., P. Guimaraes, P. Portugal and H. Reis (2014), What lies behind the returns to schooling? The role of firm level heterogeneity, Working Paper, Bank of Portugal

Chiappori, P-A and B. Salanié (2002), Testing Contract Theory: A Survey of Some Recent Work, CESifo Working Paper, published in M. Dewatripont, L. Hansen and S. Turnovsky (eds), Advances in Economics and Econometrics, Volume 1, Cambridge: Cambridge University Press

Chiappori, P-A, B. Salanié and J. Valentin (1999), Early Starters versus Late Beginners, Journal of Political Economy, 107 (4), 731-760

Guimarães, P. and Portugal, P. (2010). A simple feasible procedure to fit models with highdimensional fixed effects. Stata Journal, 10(4):628-649.

Guiso, L., L. Pistaferri and F. Schivardi (2005), Insurance within the firm, Journal of Political Economy, 113 (5), 1054-1087

Harris, M. and B. Holmstrom (1982), A Theory of Wage Dynamics, Review of Economic Studies, 49 (3), 315-33

Hartog, J. (2011), A Risk Augmented Mincer earnings equation? Taking stock. Research in Labor Economics, 33, 129-173 
Low, C. Meghir and L. Pistaferi (2013), Wage and employment risk over the lifecycle, American Economic Review, 100 (4)

Manski, C. (1993), Identification of Endogenous Social Effects: The Reflection Problem, The Review of Economic Studies, 60 (3), 531-542

Martins, P. (2014), 30,000 minimum wages: The economic effects of collective bargaining extensions, Working Paper, Queen May University of London

Matsa, D. and Gormley, T. (2014), Common Errors: How to (and Not to) Control for Unobserved Heterogeneity. Review of Financial Studies. 27(3): 617-661.

Polachek, S. (2008), Earnings Over the Life Cycle: The Mincer Earnings Function and Its Applications, Foundations and Trends(R) in Microeconomics, NOW publishers, 4(3), 165-272

Shi, S. (2009), Directed Search for Equilibrium Wage-Tenure Contracts, Econometrica, 77 (2), 561-584

Sousa, S., M. Portela and C. Sa (2015), Characterization of returns to education in Portugal:1986-2009, Working Paper from Escola de Economia e Gestão, Universidade do Minho

Tsiang, S.C. (1972), The rationale for mean-standard deviation analysis, skewness preference and the demand for money, American Economic Review, 62 (3), 354-371

Waldman, M. (2012), Theory and evidence in internal labor markets, in R. Gibbons and J. Roberts (eds), The Handbook of Organizational Economics, Princeton: Princeton University Press, chapter 10 